\title{
EVALUATION OF RED ALDER MORTALITY IN THE LITTLE CREEK WATERSHED FOLLOWING THE 2009 LOCKHEED FIRE
}

\author{
A Thesis \\ Presented to \\ The Faculty of California Polytechnic State University \\ San Luis Obispo
}

In Partial Fulfillment

Of the Requirements for the Degree

Master of Science in Forestry Sciences

By

Dylan Robert Ashton Theobald

March 2014 
(C) 2014

Dylan Theobald

ALL RIGHTS RESERVED 


\section{COMMITTEE MEMBERSHIP}

TITLE:

AUTHOR:

DATE SUBMITTED:

COMMITTEE CHAIR:

COMMITTEE MEMBER:

COMMITTEE MEMBER:
Evaluation of Red Alder Mortality in the Little Creek Watershed Following the 2009 Lockheed Fire

Dylan Robert Ashton Theobald

March 2014

Brian Dietterick, Ph.D., Director, Swanton Pacific Ranch, College of Agriculture, Food and Environmental Sciences, California Polytechnic State University

Matt Ritter, Ph.D., Professor of Biology, College of Science and Mathematics, California Polytechnic State University

Walter Mark, Ph.D., Professor of Plant Pathology, College of Agriculture, Food and Environmental Sciences, California Polytechnic State University 


\begin{abstract}
Evaluation of Red Alder Mortality in the Little Creek Watershed Following the 2009 Lockheed Fire

Dylan Robert Ashton Theobald
\end{abstract}

Five hundred eighty red alder along a $2.16 \mathrm{~km}$ portion of the Little Creek riparian zone were assessed for mortality following the 2009 Lockheed Fire near Davenport, California. The study area was divided into burn severity zones and every red alder within the riparian zone was observed and assessed for mortality. Height, diameter at breast height $(\mathrm{DBH})$, and age were collected on selected trees. An estimation of red alder large woody debris (LWD) input to Little Creek since a 2010 LWD survey (Smith, 2010) was calculated using average red alder tree dimensions applied to Smalian's formula (MLNRO, 2011). The mean proportion of dead red alder in the non-burn zone and burnzone was .11 and .45 respectively. Volume of red alder LWD in Little Creek is estimated to have increased approximately $245 \%$ since the fire. Given other factors may have played a role in red alder mortality in Little Creek, the analysis reported here supports fire also contributed to accelerated mortality of red alder established following the catastrophic debris torrent in 1955 in Little Creek. This study provides useful information regarding fire and red alder and establishes baseline conditions of the Little Creek riparian zone following the 2009 Lockheed Fire.

Keywords: red alder, Alnus rubra, wildfire, mortality, riparian, large woody debris (LWD) 


\section{ACKNOWLEDGMENTS}

I would like to thank the many individuals who helped make this research possible, especially my committee members Brian Dietterick, Matt Ritter, and Walter Mark. A special thanks goes out to Jim West for sharing his wisdom with me on many occasions. I would also like to acknowledge the team at Swanton Pacific Ranch: Steve Auten, Gordon Claassen, Mary Crable, Ashley Brubaker, Russ White, and John Hardy. I would like to acknowledge Al Smith for his foresight and generous donation of Swanton Pacific Ranch that makes hands on learning possible for so many different students. Thank you to everyone who has helped me along this research path. I have learned numerous academic and life lessons and will remember this experience for the rest of my life.

This project was funded by the California Agricultural Research Initiative, USDA McIntire-Stennis, and Cal Fire. 


\section{TABLE OF CONTENTS}

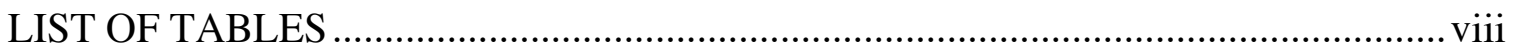

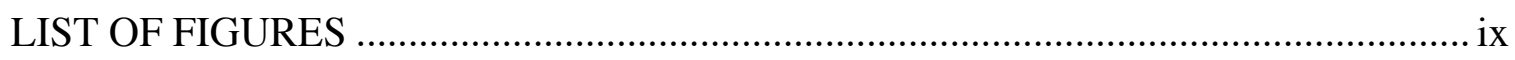

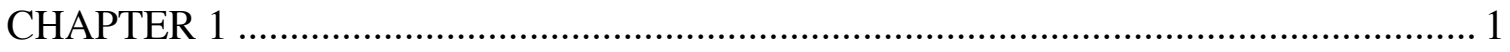

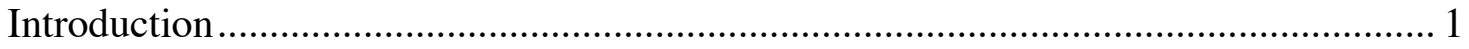

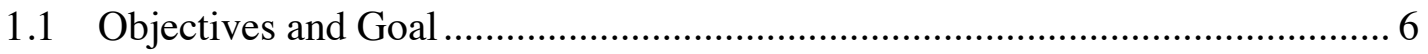

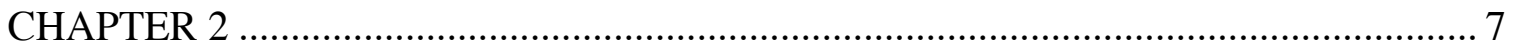

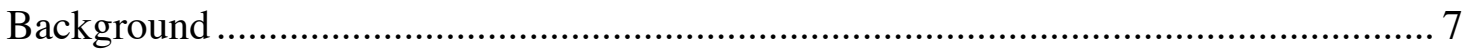

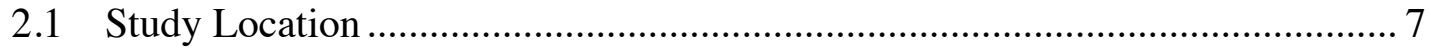

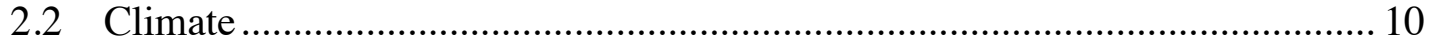

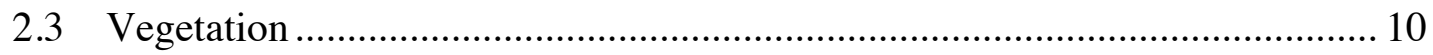

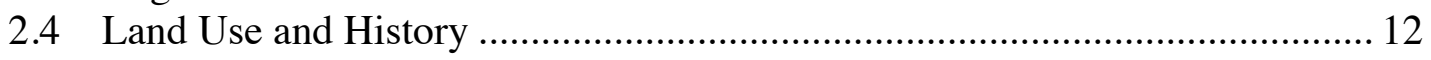

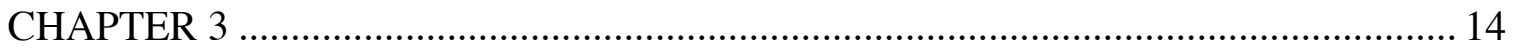

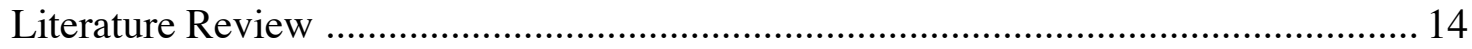

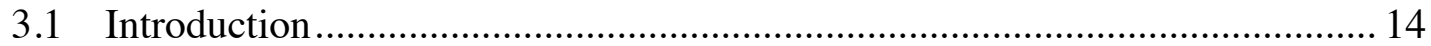

3.2 Characteristics of Riparian Zones ...................................................... 14

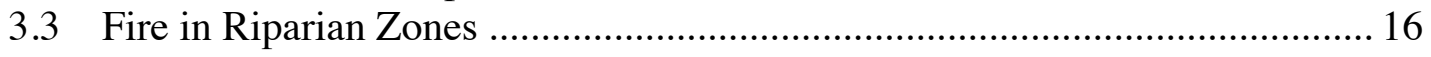

3.4 Biology \& Characteristics of Red Alder ...................................................... 17

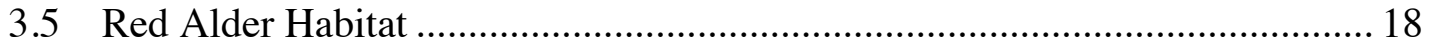

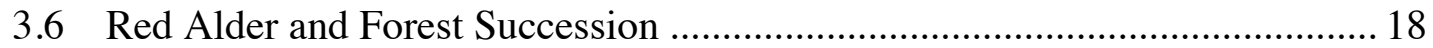

3.7 Fire and Red Alder ............................................................................ 20

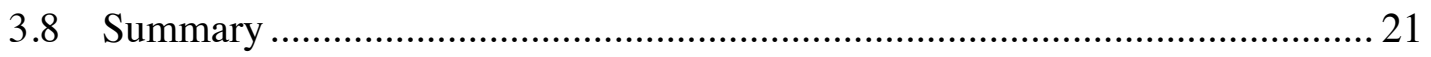

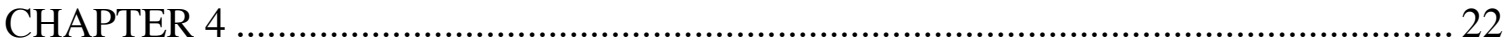

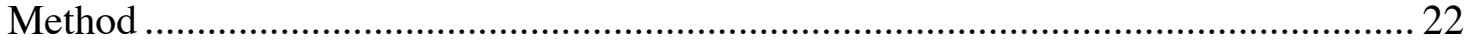

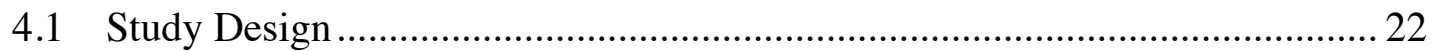

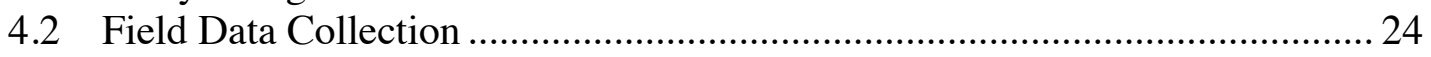

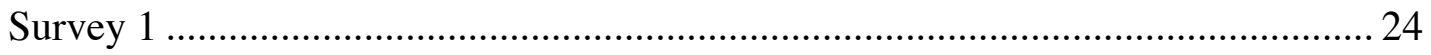

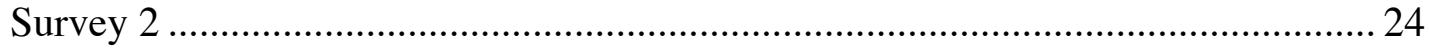

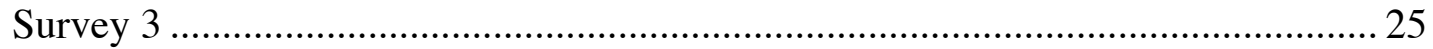

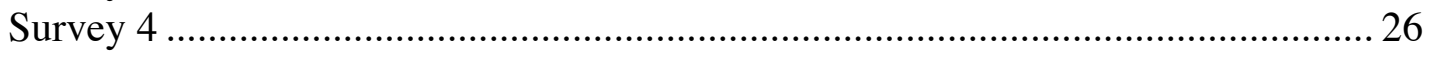

4.3 Red Alder Large Woody Debris ............................................................... 27

4.4 Assumptions for Red Alder LWD Volume Calculation ............................... 28

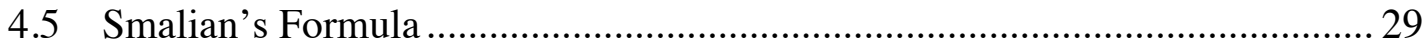

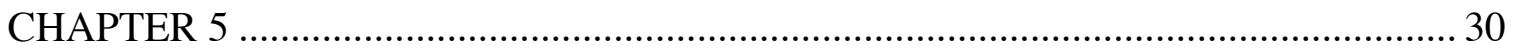

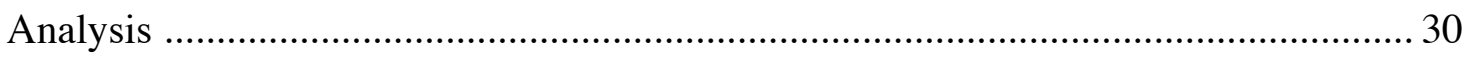

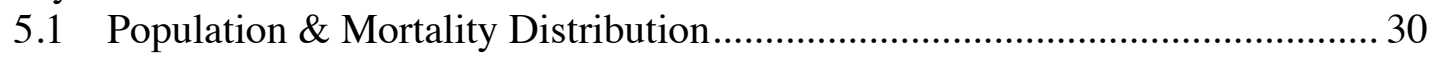

5.2 Red alder LWD Recruitment in Little Creek .............................................. 37

5.3 Spatial Characteristics of the Lockheed Fire in the Riparian Zone ................. 39

5.4 Statistical Analysis ........................................................................... 42

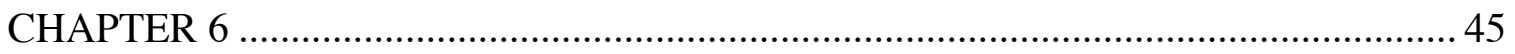

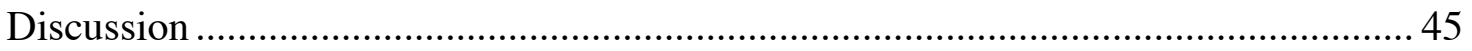

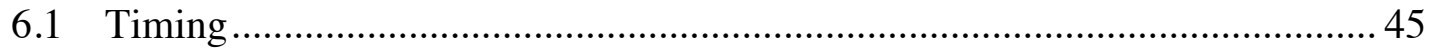

6.2 Age of Red Alder in Little Creek............................................................ 46 
6.3 Influence of Red Alder Mortality on the Little Creek Watershed ................... 47

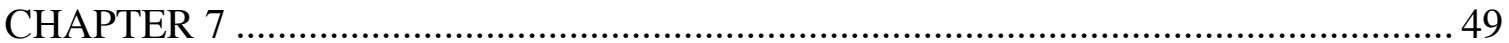

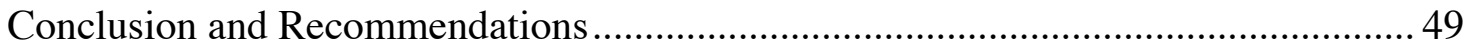

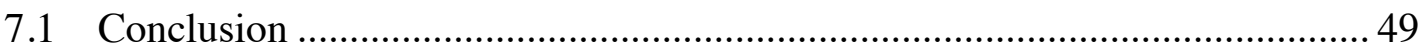

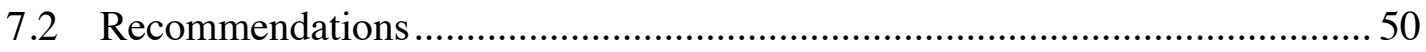

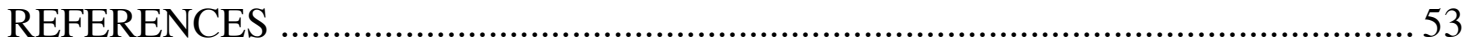

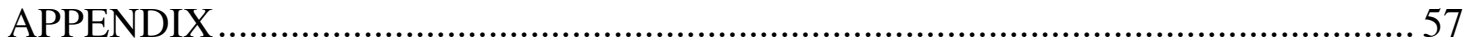




\section{LIST OF TABLES}

Table 1 - Common tree species found in the Little Creek watershed.............................. 10

Table 2 - Common Understory Vegetation Found in the Little Creek Riparian Zone ..... 11

Table 3 - Proportion of dead red alder in and out of the burn zone .............................. 31

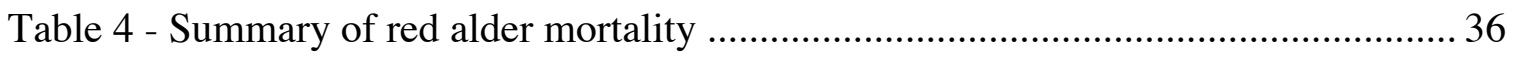

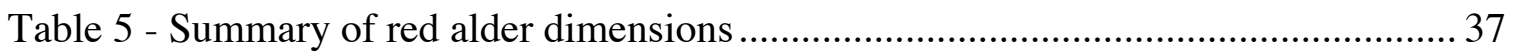

Table 6 - Summary table of red alder LWD volume in Little Creek Reaches 1-66........ 38 


\section{LIST OF FIGURES}

Figure 1 - Confluence of the North and South Forks of Little Creek .............................. 2

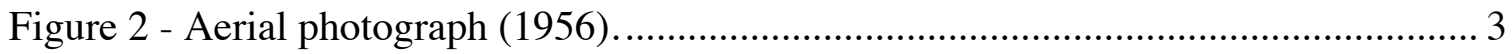

Figure 3 - Map of Lockheed Fire burn severity …................................................... 5

Figure 4 - Project area within the Little Creek watershed. .......................................... 8

Figure 5 - Cal Poly Swanton Pacific Ranch .......................................................... 9

Figure 6 - San Vicente Lumber Company Logging Operations circa 1920.................... 13

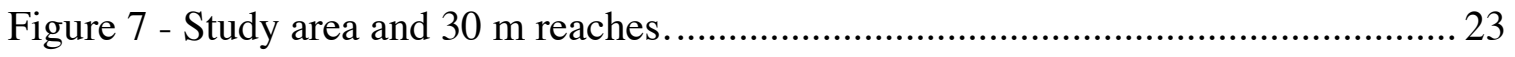

Figure 8 - Cross-section benchmarks used for referencing stream reach sections ........... 26

Figure 9 - Smalian's Formula from the Ministry of Forests, Lands and NRO 2011 ....... 29

Figure 10 - Proportion of dead red alder verses in/out of the burn zone. ....................... 31

Figure 11 - Red alder mortality in Little Creek. ........................................................ 32

Figure 12 - DBH of dead red alder in Little Creek (Hardy, 2012) ............................... 33

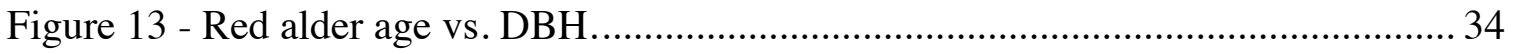

Figure 14 - Red alder tree heights in Little Creek from Survey Four (2013).................. 35

Figure 15 - Red alder heights (m) and DBH (cm) collected during survey four (2013). . 36

Figure 16 - Volume of recruited red alder LWD from 2010 - 2013 ............................ 38

Figure 17 - Top of reach 38 looking upstream (Survey Three 2012)........................... 40

Figure 18 - Lockheed Fire progression from Cal Fire ............................................. 41

Figure 19 - Probability of being alive vs. reach....................................................... 43

Figure 20 - Linear model of probability vs. reach................................................ 44 


\section{CHAPTER 1}

\section{Introduction}

Riparian zones are highly heterogeneous, biologically diverse, and function as the transitional zone between aquatic and terrestrial ecosystems (Naiman, et al., 2003). Fire in riparian zones does not occur often, but is influential in shaping vegetation dynamics and structure. Red alder (Alnus rubra Bong.) is a common tree species found in riparian areas in North America. Information regarding the sprouting response of red alder after the above ground portion of the tree has been killed by fire is lacking (Uchytil, 1989). However, red alder seldom come into contact with fire given the nature of red alder habitat. An understanding of riparian succession after fire and how fire affects red alder is valuable information for the management of riparian areas in North America.

The main stem and tributaries of the Little Creek watershed support riparian zones and several age classes of red alder. Approximately $2.3 \mathrm{~km}$ up the main stem of Little Creek, the watershed is divided by a ridge into a north and south fork. The dominant stand of red alder became established in the main stem following a catastrophic debris torrent in 1955. The exact source of the debris torrent has not been proven, but investigation by local residents and geomorphic evidence show the debris torrent likely originated from a landslide in the South Fork of the Little Creek watershed before scouring much of the inner gorge areas of the riparian corridor and depositing downstream onto the unconfined Swanton valley (Figure 1). Aerial photographs from 1956 show extensive vegetation removal and significant sediment deposition along the riparian zone of Little Creek as a result of the debris torrent (Figure 2). Co-dominant and younger classes of red alder sprouted following small landslides, above average flow 
events, and other similar disturbances resulting in exposed mineral soil. Prior to the Lockheed Fire in 2009, the dominant stand of red alder in Little Creek was healthy and typical of even-age red alder stands in the Santa Cruz Mountains.

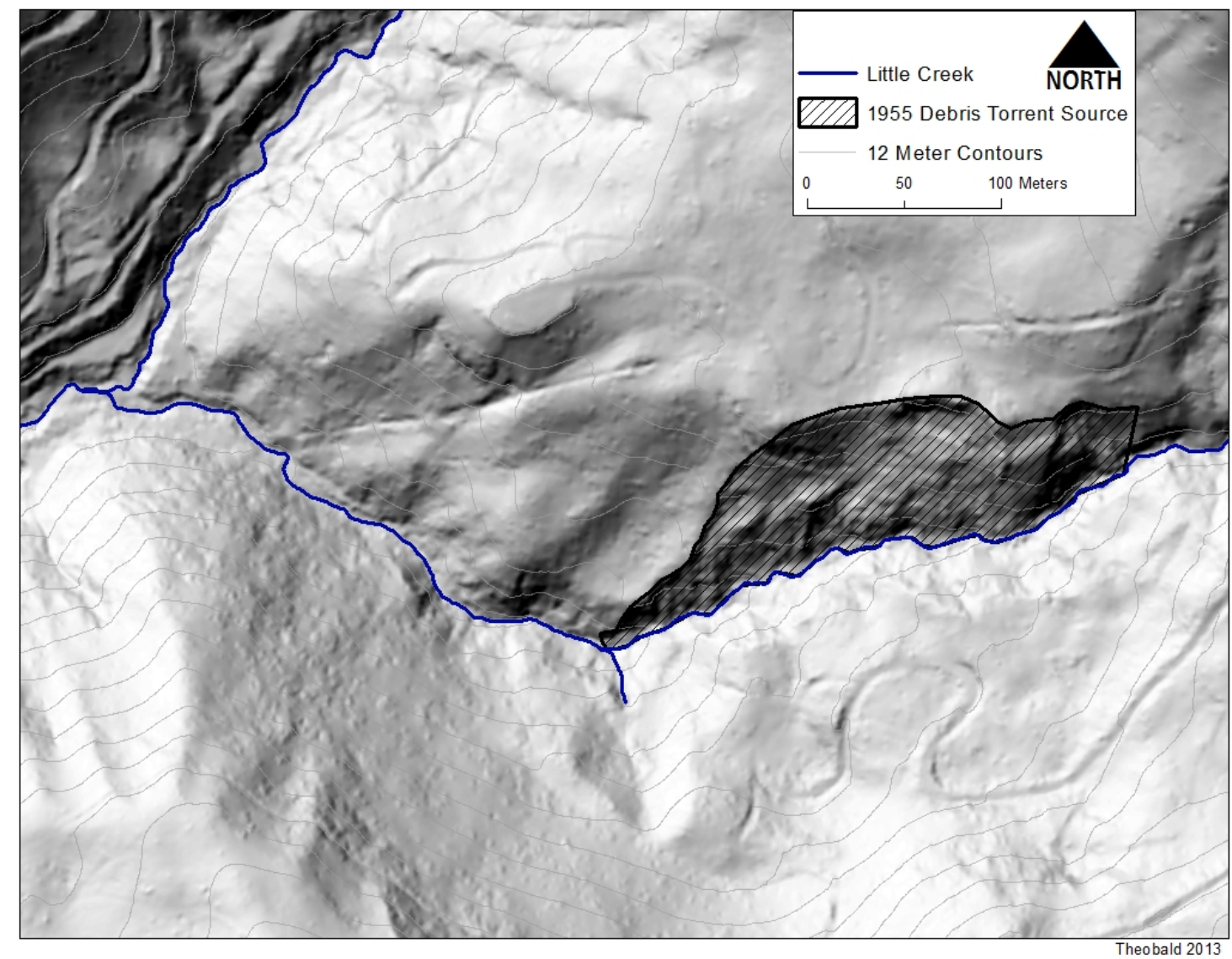

Figure 1 - Confluence of the North and South Forks of Little Creek 


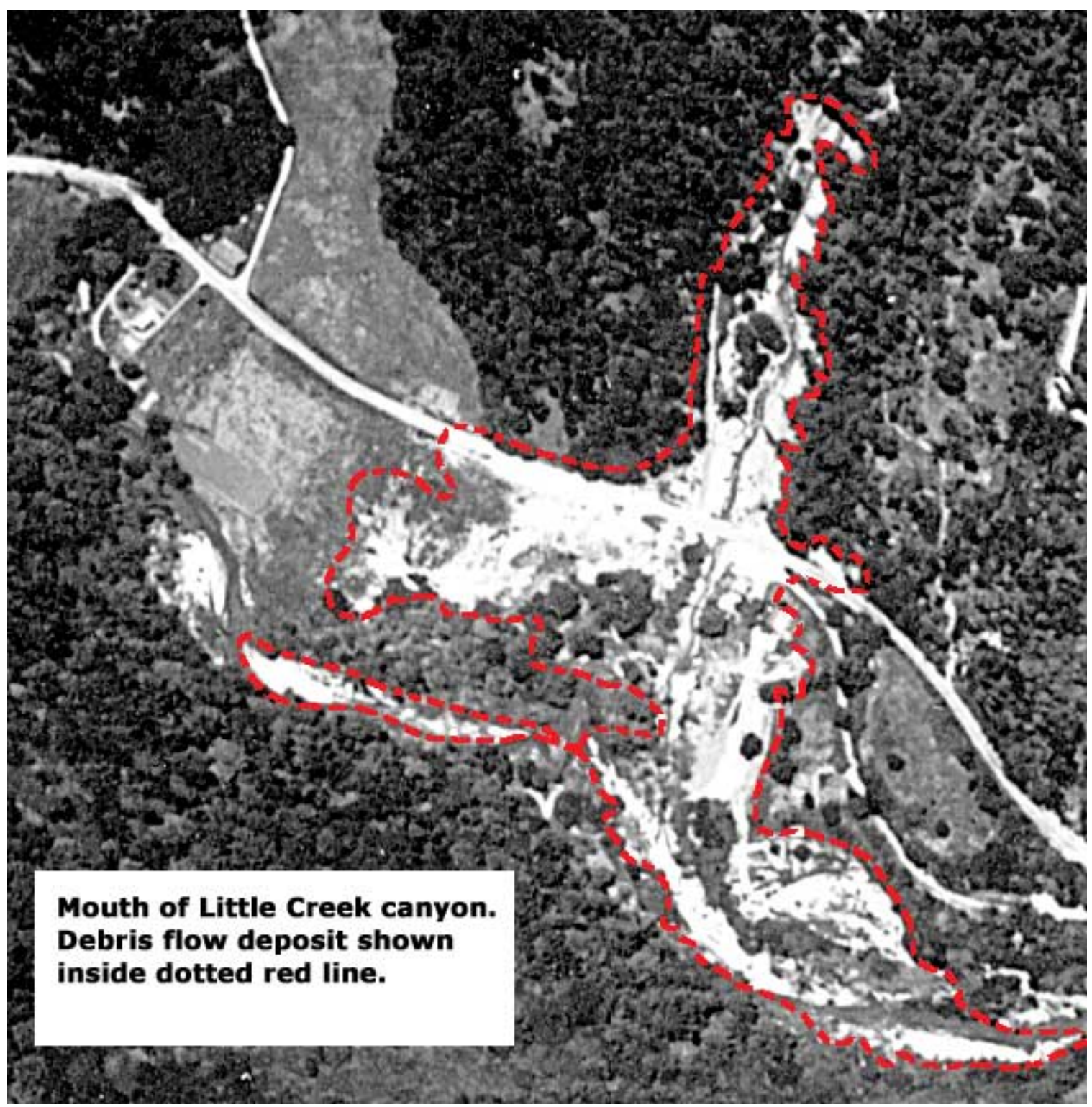

Figure 2 - Aerial photograph (1956).

In 2009, the Lockheed Fire burned 7,817 acres in total, and roughly $90 \%$ of the Little Creek watershed (Figure 3). Ignition occurred on August 12th at 19:16, on private property below the Lockheed Martin facility northeast of the town of Bonnydoon in Santa Cruz County (Dellamonica, 2009). The fire was mainly wind driven and spread rapidly along ridgelines from north to south igniting mid slope areas and then slowly back burning into the riparian zone over several days. Burn intensity varied, but some red alder were exposed to light ground fire in certain areas and litter and shrub vegetation 
was completely consumed in other areas. 8 fire crews (44 at peak 8/19/09) along with 6 helicopters fought the fire for 11 days (Cal Fire, 2009). However, fire in the riparian zone of Little Creek was extinguished over time with only minor intervention from fire crews in the lower watershed. 


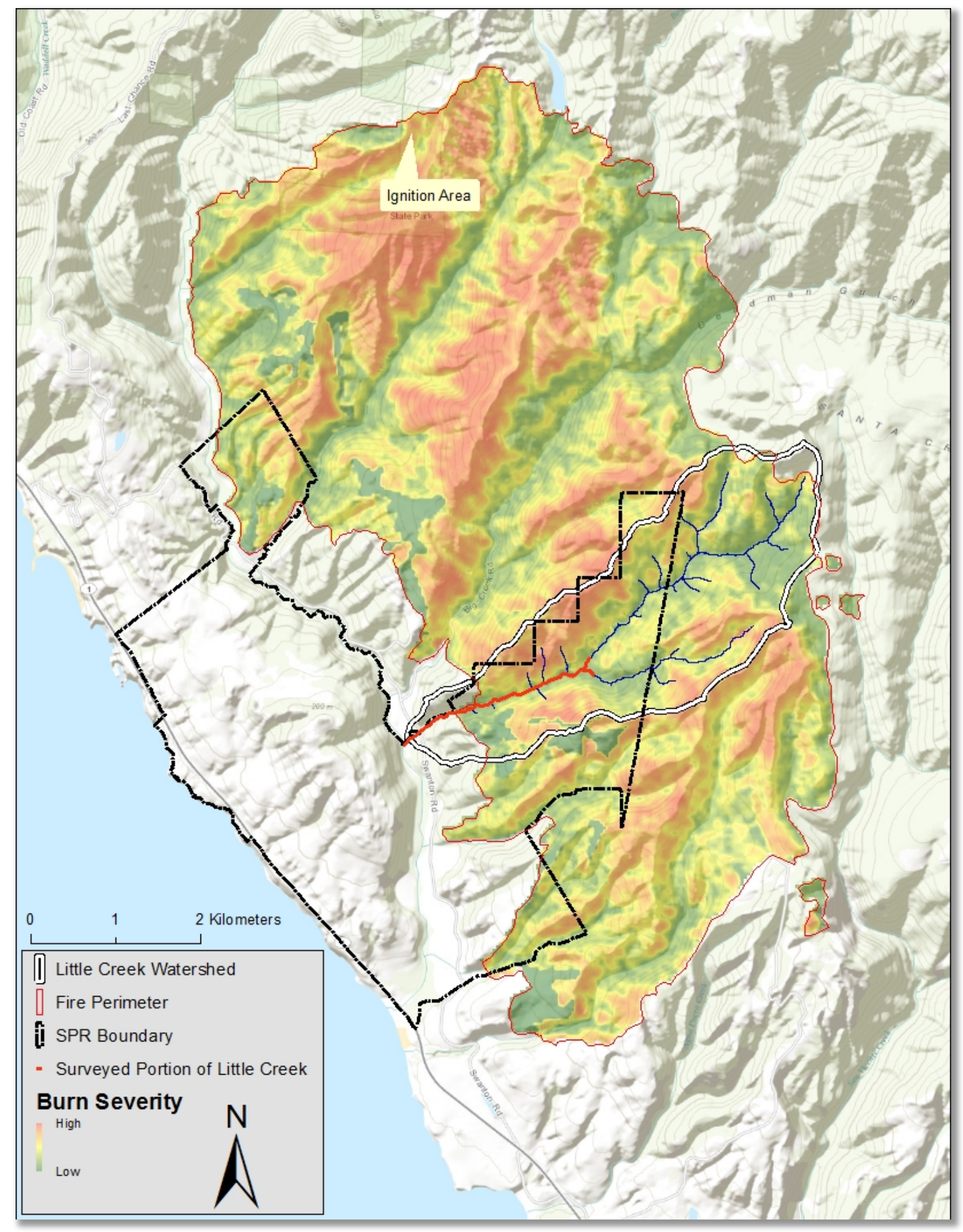

Figure 3 - Map of Lockheed Fire burn severity.

Immediately after the fire, an initial assessment of the riparian corridor along

Little Creek produced only minor signs of red alder damage (Dietterick, Pers. Comm.). 
"We have some concern over the extent of alder mortality, but from what we have observed thus far, lower-intensity burn conditions occurred in the lower elevations of lower Little Creek, making it more likely that most have survived" (Dietterick, 2009). Red alder in Little Creek produced leafy crowns in the spring of 2010, approximately 7 months after the Lockheed Fire. During the second spring after the fire (2011), significant numbers of red alder began exhibiting signs of stress and mortality. The unanticipated second-year mortality prompted further investigation.

Effects of fire on red alder have not been well reported in scientific literature. Establishing post-fire effects to overstory vegetation in the Little Creek riparian zone will create a baseline for future studies relating to riparian vegetation succession and the hydrologic function of Little Creek. Using population and mortality data to estimate the volume of red alder large woody debris (LWD) associated with the Lockheed Fire will allow for temporal analysis of LWD input in Little Creek and also establish baseline conditions for future studies. Information relating to the effects of fire on red alder will be beneficial to resource managers working in riparian areas in North America.

\subsection{Objectives and Goal}

This thesis has two objectives:

1. Determine the effects of the Lockheed Fire on red alder in the riparian zone of Little Creek.

2. Estimate the average volume per reach of red alder LWD associated with the Lockheed Fire.

The goal of this thesis is to establish post-fire baseline conditions of red alder in the riparian zone of Little Creek. 


\section{CHAPTER 2}

\section{Background}

\subsection{Study Location}

The study area is located in the Little Creek watershed, $90 \%$ of which was burned by the Lockheed Fire (Figure 4). 57\% of the Little Creek watershed is located on Cal Poly's Swanton Pacific Ranch near Davenport, California (Figure 5). Little Creek is a tributary to Scotts Creek, which flows to the Pacific Ocean underneath California Pacific Coast Highway 1. The elevation within the watershed ranges from 550 meters on the ridgeline to 9 meters at the confluence with Scotts Creek. Little Creek is a steep, narrow watershed with an average slope of $45 \%$ (White, 2010). Little Creek contains first, second, and third order tributaries as defined by Strahler (1964), and class 1, 2, and 3 streams, as defined by the California Forest Practice Rules (CDF, 2013). 


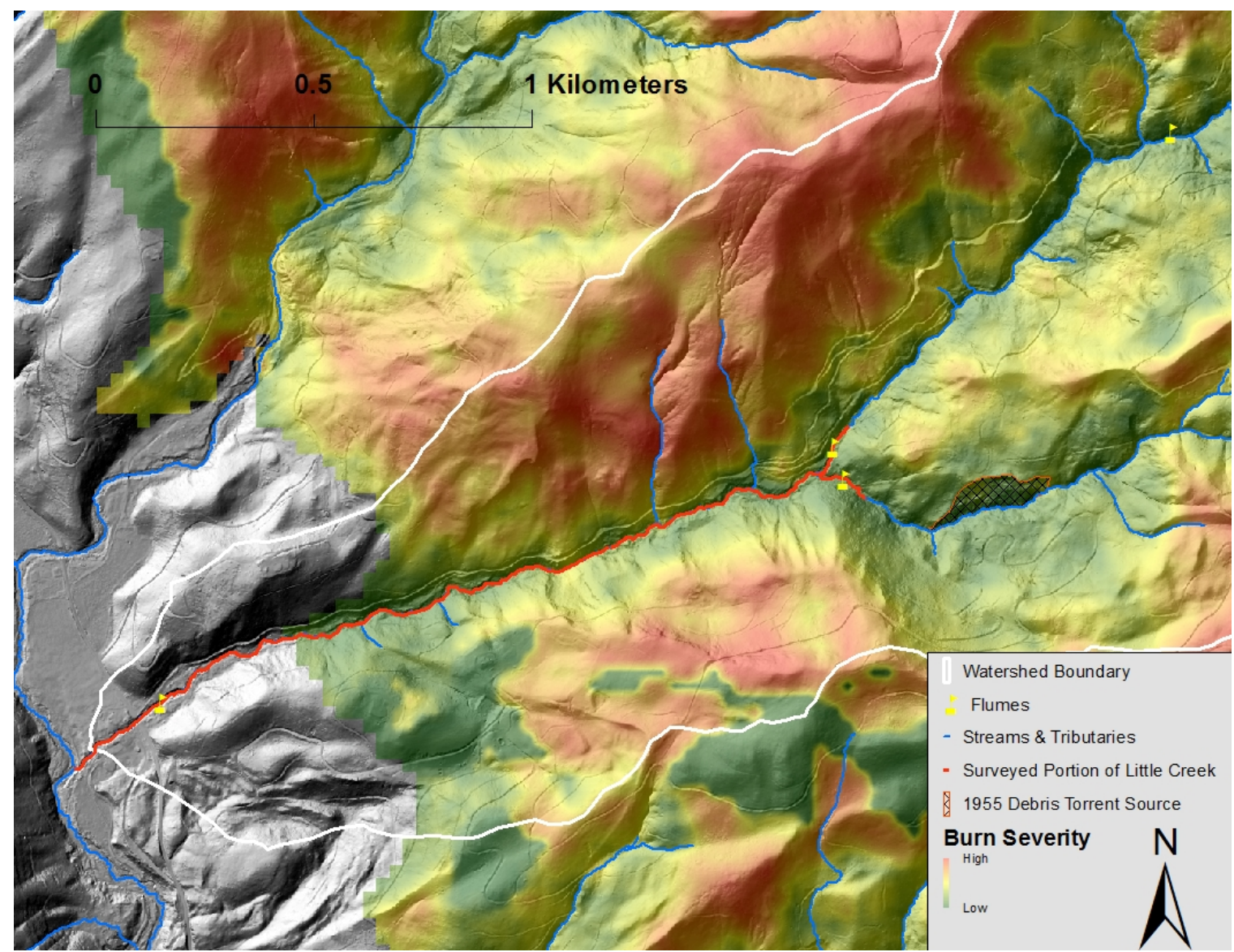

Figure 4 - Project area within the Little Creek watershed. 


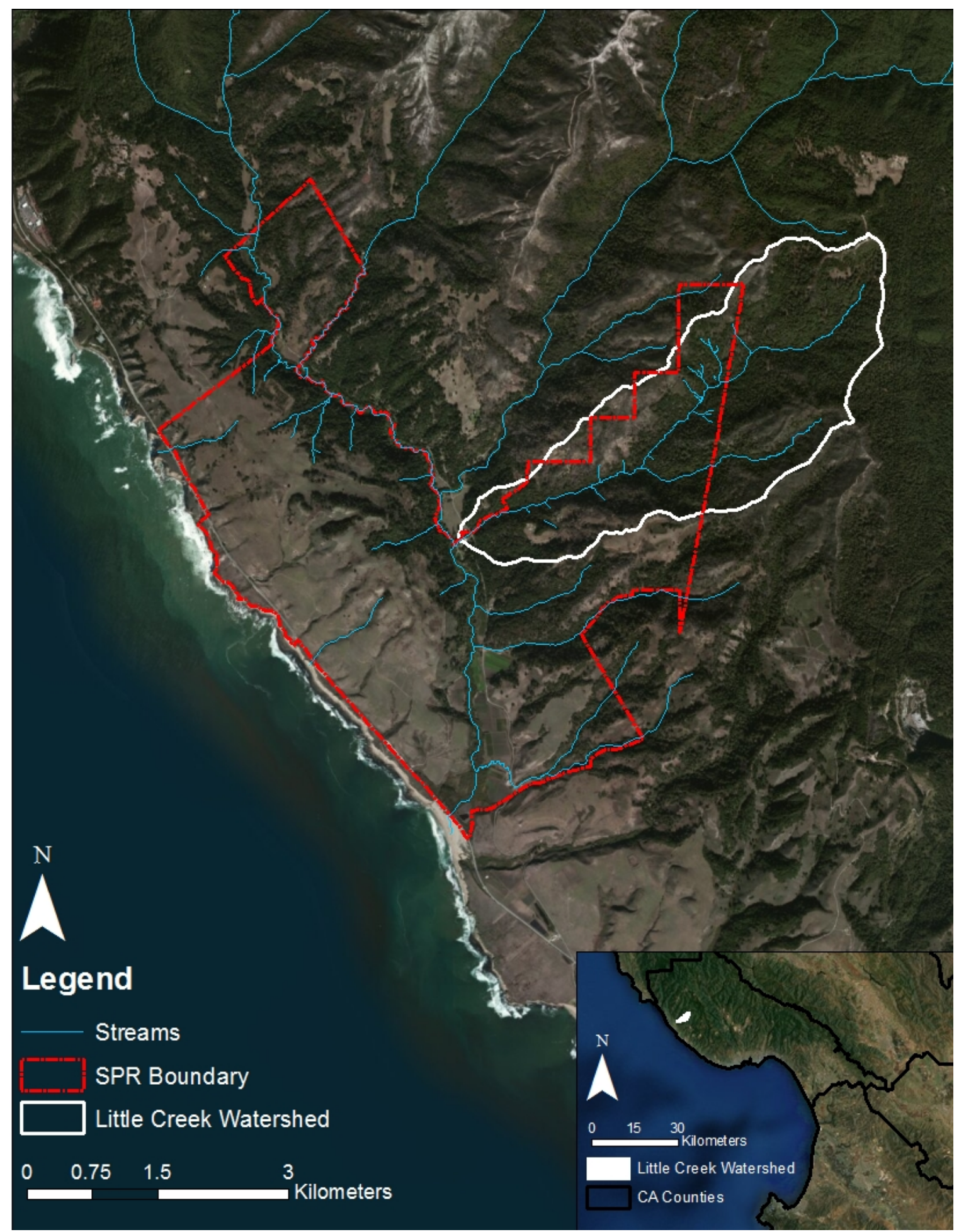

Figure 5 - Cal Poly Swanton Pacific Ranch 


\title{
2.2 Climate
}

The Little Creek watershed is located in a Mediterranean climate characterized by warm dry summers and cool wet winters. The majority of the annual precipitation falls from October to May. Average annual precipitation at higher elevations is approximately $125 \mathrm{~cm}$ a year and $75 \mathrm{~cm}$ closer to sea level. Snow is very rare.

\subsection{Vegetation}

Overstory canopy in the Little Creek watershed consists of redwood and Douglas fir. The upper hillslopes and ridgelines are dominated by knobcone pine and chaparral, particularly on southern aspect slopes. Red alder is the dominant tree species within the riparian zone. Tan oak, bay laurel, nutmeg and big leaf maple are also found throughout the watershed. A survey of Little Creek road, which is adjacent to Little Creek, indicated over 120 different plant species (West, 2009). Tables 1 and 2 list common plant species found within the Little Creek watershed.

Table 1 - Common tree species found in the Little Creek watershed.

Redwood

Douglas Fir

Tan Oak

Big Leaf Maple

Red Alder

Buckeye

Bay Laurel

Madrone

Knobcone Pine

Nutmeg

Arroyo Willow

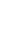

\section{Common Name}

\author{
Common Name
}


Table 2 - Common Understory Vegetation Found in the Little Creek Riparian Zone

\section{Common Name}

Redwood Sorrel

California Wild Lilac

Miner's Lettuce

Poison Oak

Thimbleberry

Common Snowberry

Western Sword Fern

Five-Finger Fern

Lady Fern

Elderberry

Trillium

California Blackberry

Elk Clover

Stinging Nettle

\section{Scientific Name}

Oxalis oregana Nutt.

Ceanothus thyrsiflorus Eschsch

Claytonia perfoliata Donn ex Willd.

Toxicodendron diversilobum (Torr. \& A.

Gray) Greene

Rubus parviflorus Nutt.

Symphoricarpos albus (L.) S.F. Blake

var. laevigatus (Fernald) S. F. Blake

Polystichum munitum (Kaulf.) C. Presl

Adiantum aleuticum (Rupr.) C.A. Paris

Athyrium filix-femina (L.) Roth

Sambucus

Trillium

Rubus ursinus Cham. \& Schltdl.

Aralia californica $S$. Watson

Urtica dioica $L$.

*Little Creek is likely the only subwatershed within the Scotts Creek watershed that does not contain Salmon Berry Rubus spectabilis Pursh (West, Pers. Comm.). 


\subsection{Land Use and History}

Before the mid 1800's, the Santa Cruz Mountains in and around the study area were inhabited by the Ohlone (Costanoan) people. Shell middens have been found on The Ranch dating back to 6,300 BC (Colgate, 2001). The Costanoans lived by hunting, fishing, and gathering, and used fire as a method of managing the landscape. Many of the fire-adapted species present today may be associated with fire management practiced by the Ohlone (West, Pers. Comm.).

The Mexican Portola party arrived in 1769. The original Spanish land grant in the area was titled Rancho Agua Puerca y Las Trancas and was under the ownership of early settler James Archibald in the 1860's. Archibald later arranged for a Swiss dairyman, Ambrogio Gianone to manage the land as a dairy. Gianone is responsible for the now known as Casa Verde, the Queseria, and large barn still standing today adjacent to Swanton Road. Between 1906 and 1922, the Santa Cruz Mountains were heavily logged in order to supply lumber for rapidly developing cities nearby (Figure 6) (Swanton Pacific Railroad Society). 


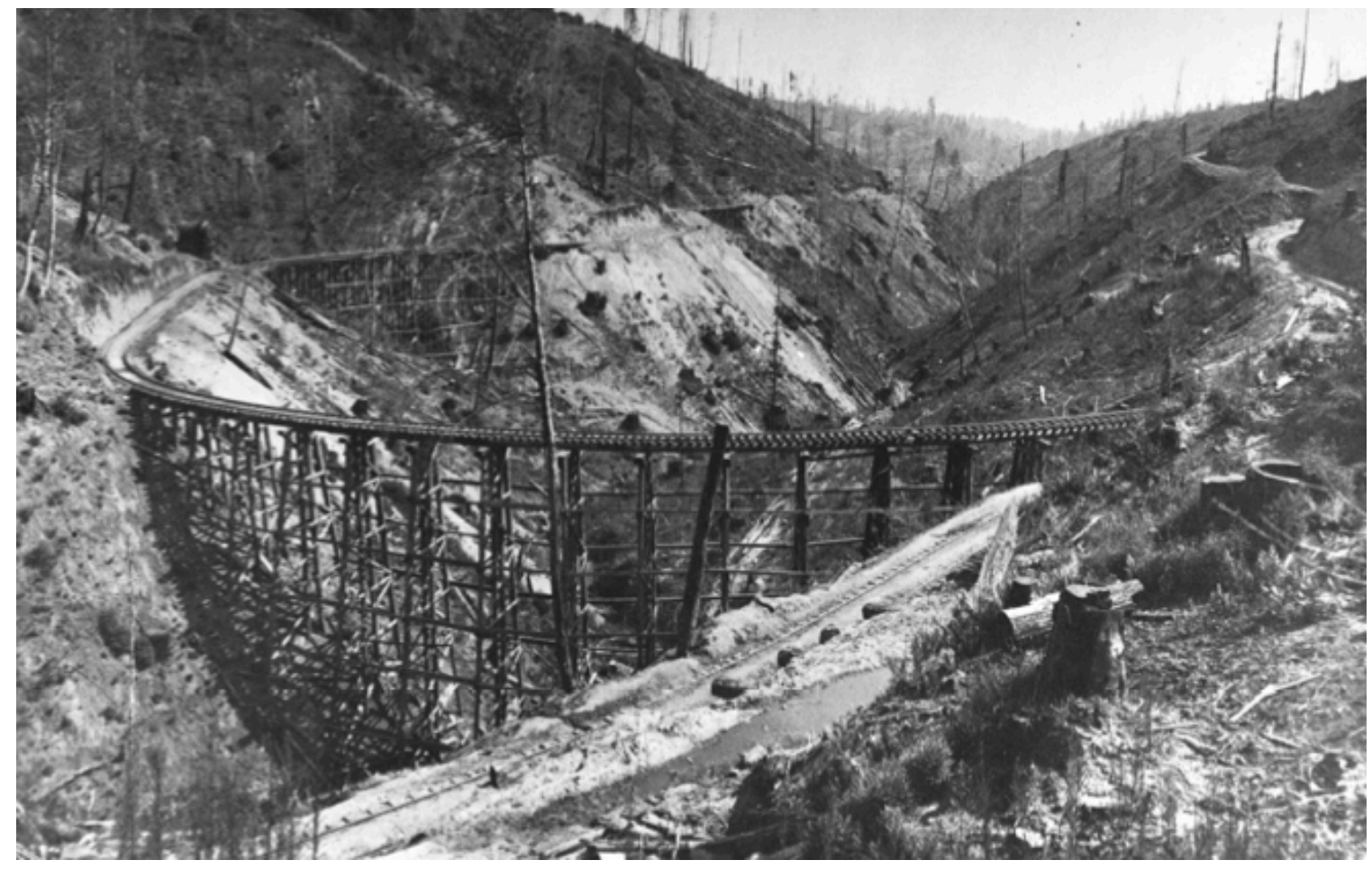

Figure 6 - San Vicente Lumber Company Logging Operations circa 1920.

At the age of nineteen, Albert B. Smith purchased his first parcel in Swanton. By the 1970's, Al Smith had acquired several more parcels, which make up the current 3200 - acre Swanton Pacific Ranch Property. In 1993, Al donated the land to California Polytechnic State University with the goal of creating a living-learning laboratory for students to utilize in perpetuity. Today, Swanton Pacific Ranch hosts educational and research opportunities in organic farming, forestry, livestock management, and watershed management. The Little Creek watershed serves as the School Forest and is actively harvested for redwood and Douglas-fir as part of a non-industrial timber management plan (NTMP). A series of research projects initiated an ongoing water qualitymonitoring plan currently supervised by Cal Poly Students. Approximately 500 students from Cal Poly visit Swanton Pacific Ranch every year for field trips and short courses. 


\section{CHAPTER 3}

Literature Review

\subsection{Introduction}

Riparian zones are highly heterogeneous, biologically diverse and provide the interface between many terrestrial and aquatic ecosystems (Naiman, et al., 2003). Fire in riparian areas is rare compared to neighboring uplands, but can have a significant impact on vegetation, large wood (LWD) recruitment, stream morphology, and stream temperature (Halofsky et al., 2008). Red alder is a common species in riparian areas along the west coast of North America and contributes to bank stabilization, habitat, LWD, and soil nitrogen content. Riparian zones are disproportionately important to many uses, making them a critical area for multi-use planning (Thomas et al., 1979). Due to its rare occurrence, little research has been conducted on the effects of fire in riparian ecosystems (Pettit \& Naiman, 2007).

\subsection{Characteristics of Riparian Zones}

Distinguished by proximity to flowing water and hydrophilic vegetation, riparian areas are transitional zones between waterways and the terrestrial landscape around them. Definitions of riparian areas vary depending on the agency or discipline involved, and many are consistent in identifying the soil vegetation complex as differentiating criteria between a riparian area and its neighboring uplands (Anderson, 1987). Other definitions emphasize spatial information and the interaction between aquatic and terrestrial ecosystems. Regardless of the specific terms used in distinguishing riparian zones, riparian zones are critical to the function of stream ecosystems and provide the interface for land-water interactions. 
Riparian areas are unique ecosystems utilized by wildlife disproportionately more than other habitat types (Thomas, et al., 1979). In California, 25\% of mammals, $80 \%$ of amphibians, and $40 \%$ of reptiles inhabit or depend on riparian zones (Sorenson, 1989). The riparian canopy provides refugia and food sources for terrestrial and aquatic life and influences stream temperature by generating shade. Streams and riparian zones are often used as flyways for birds. Organic matter produced from riparian vegetation, along with other biophysical processes, support many food webs both on land and in the stream (Naiman et al., 2003). Fallen leaves provide food for macroinvertebrates in the stream and down trees contribute large woody debris (LWD) that in turn provides habitat complexity benefiting aquatic life.

Increased availability of water creates abundant vegetation from a large variety of species. Riparian vegetation plays an important role in bank stability, stream temperature, and water quality. Complicated root systems help to bind soil and increase infiltration rates (Maser \& Sedell, 1994). Vegetation along stream channels influences stream velocity by increasing channel roughness along the stream bank. A dynamic relationship exists between riparian areas and the hyporheic zone, resulting in riparian vegetation being more hydrologically connected to streamflow than vegetation located upslope (Dwire \& Kauffman, 2003). Although no two riparian zones are the same, vegetation trends are related to elevation, stream width, stream pitch and pitch of the sideslope. Wider streams generally have less conifer basal area and less canopy cover than narrow streams. Streams with steeper gradients tend to be dominated by conifers; whereas lower gradient streams are dominated by hardwoods (Minore \& Weatherly, 1993.) 
Topographic location, canopy cover, and the presence of water create microclimates in riparian areas that are generally cooler and damper than the areas around them (Dwire \& Kauffman, 2003). These microclimates are important in shaping ecological processes and ecosystem function including the frequency and severity of fire.

\subsection{Fire in Riparian Zones}

Fire in riparian zones is an infrequent occurrence, but can have significant ecological impacts (Pettit \& Naiman, 2007). Climate (Agee, 1993), along with the riparian physical environment, have the biggest influence on the effects of fire in the riparian zone. Elevation, stream order, vegetation cover and previous land use and management practices also influence the effects of fire (Pettit \& Naiman, 2007).

Elevation and stream order have an effect on riparian zone vegetation dynamics. Riparian vegetation in higher order streams at lower elevations tend to have more hardwood species, experience less fire severity, and regenerate with hardwood species after fires. Alternatively, riparian areas along lower stream orders at greater elevations are characterized by more conifer basal area and experience higher fire severity (Halofsky \& Hibbs, 2009). Fires that occur in headwater streams can influence downstream reaches by creating sources of nutrients, sediment and LWD (Pettit \& Naiman, 2007).

Riparian areas have a greater amount of vegetation coverage when compared to neighboring uplands. However, landscape features and close proximity to water increases fuel moisture content often decreasing fire severity (Agee et al., 2002). Fire severity in the Biscuit (2002) and B\&B Complex (2003) in Oregon, were both less severe in the riparian areas affected by the burn. Exposed mineral soil and char height on trees in the riparian zone were less severe than the adjacent uplands. However, there was no 
significant difference between crown scorch and basal area mortality between the riparian zone and upland area (Halofsky \& Hibbs, 2008).

Land use practices throughout the past century have resulted in many changes affecting fire severity in both uplands and riparian areas. Reduced frequency of fires has resulted in increased fuel loads. Watershed modifications have resulted in altered flow rates and vegetation coverage in riparian areas. The "terrestrialization" of riparian areas as a result of diverted flow paths or decreased precipitation patterns over long periods of time can result in riparian vegetation resembling upland vegetation and, in turn, sharing a similar fire regime (Naiman et al,. 2005). Under some circumstances, riparian zones can function as pathways for fire to spread if a large amount of fuel has accumulated and dried out from a lack of moisture (Agee, 1998).

Increased availability of water to vegetation frequently decreases recovery time after major disturbances such as flooding or fire. Short-term effects of fire on aquatic communities are temporary unless the systems have already been significantly impaired by previous disturbances or human intervention (Reeves et al., 2006). However, fire in riparian zones can often decrease canopy cover resulting in elevated stream temperatures until the regeneration of streamside vegetation. There are many interrelated factors affecting fire regimes in riparian areas and many opportunities for research.

\subsection{Biology \& Characteristics of Red Alder}

Red alder (Alnus rubra Bong.), a member of the family Betulaceae, is a common tree species in moist, mineral soils, at low elevations on the west coast of North America. Red alder is a shade intolerant, pioneer species characterized by rapid juvenile growth, the ability to fix nitrogen from the atmosphere and a relatively short life span $(<100$ years) (Worthington et al., 1962). Disturbance sites such as avalanche shoots, skid trails, 
debris flows and recently deposited sandbars are common habitat for red alder.

Historically, forest managers have tried to eliminate red alder in order to encourage more profitable associated conifer species (Harrington et al., 2006). However, awareness regarding the value of red alder as a method of increasing soil nitrogen content and the use as of red alder as an alternative hardwood has been increasing.

\subsection{Red Alder Habitat}

Red alder habitat ranges from southern California to southeastern Alaska. Red alder most commonly grow within $200 \mathrm{~km}$ of the coast and below $750 \mathrm{~m}$ elevation (Harrington, 2006). Although red alder is rare east of the Cascades in Oregon and Washington or the Sierra Nevada in California, small isolated populations have been found in northern Idaho (Johnson, 1968).

Red alder can tolerate poorly-drained soils and occasional flooding. The ability of red alder to fix atmospheric nitrogen, allows it to grow on geologically young or disturbed sites with low levels of soil nitrogen (Hibbs, 1994). Pollen records from the Pacific Northwest indicate an increase in alder populations as human disturbance has increased (Davis, 1973).

\subsection{Red Alder and Forest Succession}

Red alder is a short-lived, shade intolerant pioneer species and is often outcompeted by longer-living conifer trees or understory vegetation after a significant amount of time has passed without any major disturbances (Harrington et al., 1984). Red alder is generally monoecious and produce light seeds (800-3000 per gram) that can travel long distances (Harrington et al., 1994). Primary dispersal is through wind, but water and animals can also transport seeds. As an intolerant pioneer species, red alder 
colonizes in recently disturbed areas, and does not compete well. Germination of red alder seeds is strongly influenced by light, and reduced by the presence of understory vegetation (Harrington et al., 1994). Recently logged areas, avalanche shoots, and flood plains often contain sections of exposed mineral soil where red alder sprout. Red alder experiences rapid juvenile growth, in some cases reaching over two-thirds its mature height by age 30 (Harrington \& Curitus, 1986). In ideal conditions, red alder can grow to be 30-40 meters tall and 55-75 centimeters in diameter (Harrington, 2006). The American Forests Big Tree champion red alder in Oregon measured $158 \mathrm{~cm}$ at DBH, but trees over DBH of $90 \mathrm{~cm}$ are rare (Harrington, 2006). Climate strongly influences seasonal growth.

Red alder grows three varieties of branches: sylleptic (developed from a bud grown during the current season), proleptic (developed from a bud grown the previous season), and epicormic (developed from suppressed buds that are triggered to grow by injury or dramatic change in environment). Live red alder trees have very little decay compared to other hardwood species. Where damage does occur, red alder are efficient at compartmentalizing decay, preventing its spread (Harrington, 2006).

Harrington (1984) field trial found when 4-year-old planted red alder were cut at five stump heights $(0,10,30,50$, and $70 \mathrm{~cm})$ during 4 different months out of the year (January, May, July, and September), the number of stumps surviving was greatest in January at $30 \mathrm{~cm}$ and lowest at 0 and $10 \mathrm{~cm}$ cut during July and September. Younger stumps experienced more vigorous epicormic sprouting compared to older stumps. Red alder cut at 0 and $10 \mathrm{~cm}$ experienced greater mortality. Plots cut in July experienced far more $2^{\text {nd }}$ year mortality then the other months (Harrington, 1984). The resprouting potential of red alder is influenced by timing, age, and severity of disturbance. 
The growth characteristics of red alder often produce leaning trees as a function of light distribution. Seedlings can permit small amounts of shade for a few years, but only trees with dominant or codominant crown positions will survive. Rooting patterns of red alder are a function of soil characteristics and tree size. Root growth in poorly drained soils is surface oriented and influenced by water availability in well-drained soils (Harrington et al., 2006). Mature, taller red alder in saturated soils will often topple over as wind throw before reaching senescence. Red alder have nitrogen-fixing capabilities in their root systems, which are home to a symbiotic relationship between the tree and actinomycete (Frankia spp.) (Harrington, 2006). The primary mechanism for nitrogen transfer into the soils has been suggested to be through leaflitter fall (Boremann et al., 1994). The nitrogen fixing abilities of red alder influence ecosystem function and nitrogen export into watersheds (Compton et al., 2003).

Very few damaging agents are a threat to red alder, especially when the tree is young and uninjured. Potential threats increase with damage and as management is intensified as in nursery or plantation environments. Exposed red alder wood quickly turns from white to red or brownish orange in color and is the reason for the name "rubra". Once damaged or cut, red alder will decay rapidly (Harrington, 2006). LWD generated from red alder will not last as long as associated conifer species because of the high cellulose content of red alder wood. However, LWD generated from red alder is still an important stream feature and can have many morphological influences to a stream system.

\subsection{Fire and Red Alder}

Red alder is a fire and flood "invader," colonizing in recently disturbed sites (Agee, 1993). Fire damage to red alder is rare because most of the habitat common for 
red alder stands is not prone to wildfires. In some cases, red alder has even been used as a firebreak to protect adjacent conifers (Worthington et al., 1957).

In the June 1999, Whatcome Creek Fire in Bellingham, Washington, where a gasoline leak resulted in an approximately 15-minute fire directly in the stream channel, alder on the right bank (lower intensity fire) experienced $66 \%$ mortality. $45 \%$ of the surviving alder produced new leafy crowns the following year. Alder on the left bank (higher intensity fire) experienced $76 \%$ mortality. None of the surviving alder on the left bank produced leafy crowns the following spring. However, 10 trees produced epicormic sprouts from the bole (Fonda, 2001). The Whatcome Creek Fire was a unique situation in that the fire burned with intensity for only 15 minutes and had tall flames directly in the stream channel.

Fire scars on the boles of red alder in Tillamook Oregon reveal trees were lightly burned and survived the 1939 and 1945 fires. However, details on the effects of the fire on red alder were not further investigated (Bailey \& Poulton, 1967). Although exposure to fire is uncommon, observations have shown red alder to be relatively fire resistant to low to moderate intensity fires.

\subsection{Summary}

Effects of fire on riparian ecosystems will often differ from neighboring uplands in intensity because of distinctions in geomorphology, vegetation, hydrology, and microclimate. Red alder is a common tree species in riparian areas on the west coast of North America and have some tolerance for low intensity fire. Because of the lack of research and potential for increased frequency of fire in riparian zones given a changing climate, more research is needed on fire and red alder and the effects of fire on riparian ecosystems. 


\section{CHAPTER 4}

Method

\subsection{Study Design}

An observational study was performed utilizing field data and personal accounts of the 2009 Lockheed Fire in order to describe how the fire influenced red alder mortality and the riparian zone of Little Creek. Four red alder field surveys were conducted from August 2011 to November 2013.

Little Creek was previously divided into 66 study reaches from the confluence of Scotts Creek and Little Creek to the North and South Forks of Little Creek (Figure 7). Subdividing the riparian area along Little Creek into study reaches allowed for tree population and mortality to be quantified and compared over defined spatial boundaries. Each reach is marked by a rebar stake previously established in 2002 as part of the Little Creek Project, an ongoing watershed study looking at channel cross-sectional and longitudinal profiles. The distance between each rebar stake is approximately $30 \mathrm{~m}$ (100 ft) and was measured using a cloth drag tape pulled taught up the center of the stream channel. The total number of red alder were counted in each reach as well as noting the status of trees i.e. live or dead. Diameter, height, and age were also collected on a representative sample of red alder during survey one and survey four. Notes and photographs relating to fire severity, vegetation dynamics, and geomorphic features were also collected. 


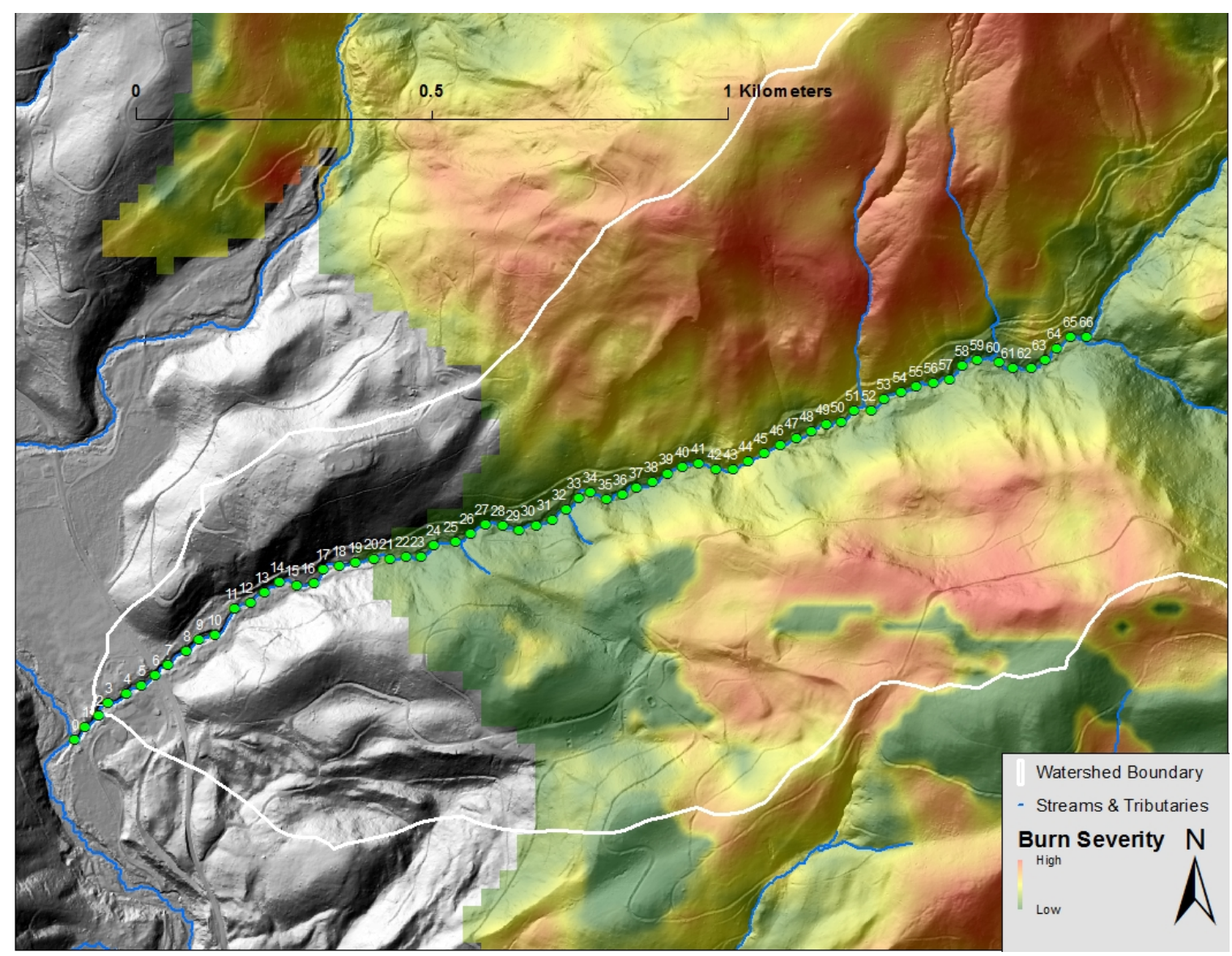

Figure 7 - Study area and $30 \mathrm{~m}$ reaches. 


\subsection{Field Data Collection}

\section{Survey 1}

The first survey was conducted in August 2011 in partial fulfillment of a senior project (Hardy, 2012). Every red alder with a diameter at breast height (DBH) greater than $10 \mathrm{~cm}$ (4 in) located within the study area was counted and noted as live or dead. DBH was collected on each dead red alder and every red alder within seven randomly selected reaches $(23,24,38,44,45,59, \& 63)$ using a Biltmore stick. Logistic regression was used to test the significance of the burn zone (in/out), elevation, and survey year (2011 vs. 2012). Results from Hardy's 2012 senior project survey indicated the burn zone was the only significant factor associated with red alder mortality and the difference between Survey 1 and Survey 2 was not statistically significant.

\section{Survey 2}

The second survey was completed in June 2012, after making minor adjustments to the survey protocol. Both surveys had the same objective of mapping and quantifying red alder mortality in Little Creek. As in the first survey, red alder within the riparian zone of Little Creek were counted and assessed for mortality. Mortality was determined visually based on physical status of the tree and whether or not foliage had been produced. The second survey was conducted in June, when living red alder bear leaves. Red alder lacking foliage were categorized as dead. Evidence of the Lockheed Fire such as scorch marks and vegetation disturbance were documented through photographs and field notes.

A GPS point was collected in the center of the stream at each reach marker using a Garmin GPS. Sixty seconds of calibration time was allowed for each point. The 
incised stream channel and steep topography of the watershed resulted in poor GPS to satellite communication and variable accuracy among reaches. Reviewing the GPS points in GIS after the survey showed the points required further ground verification in order to meet the desired accuracy of \pm 50 feet.

\section{Survey 3}

A third survey was conducted in May 2013 with the objectives of improving the accuracy of the previously collected GPS points of rebar monuments, and further investigating fire severity.

Upon analysis of the GPS points collected during the second survey, it was determined several points did not meet the minimum desired accuracy of \pm 50 feet. The location of reaches $12,26,28,61$, and 63 could be checked by measuring the slope distance from several known locations that were established and georeferenced with a total station in Spring 2002 (Figure 8) (Perkins, 2012). 


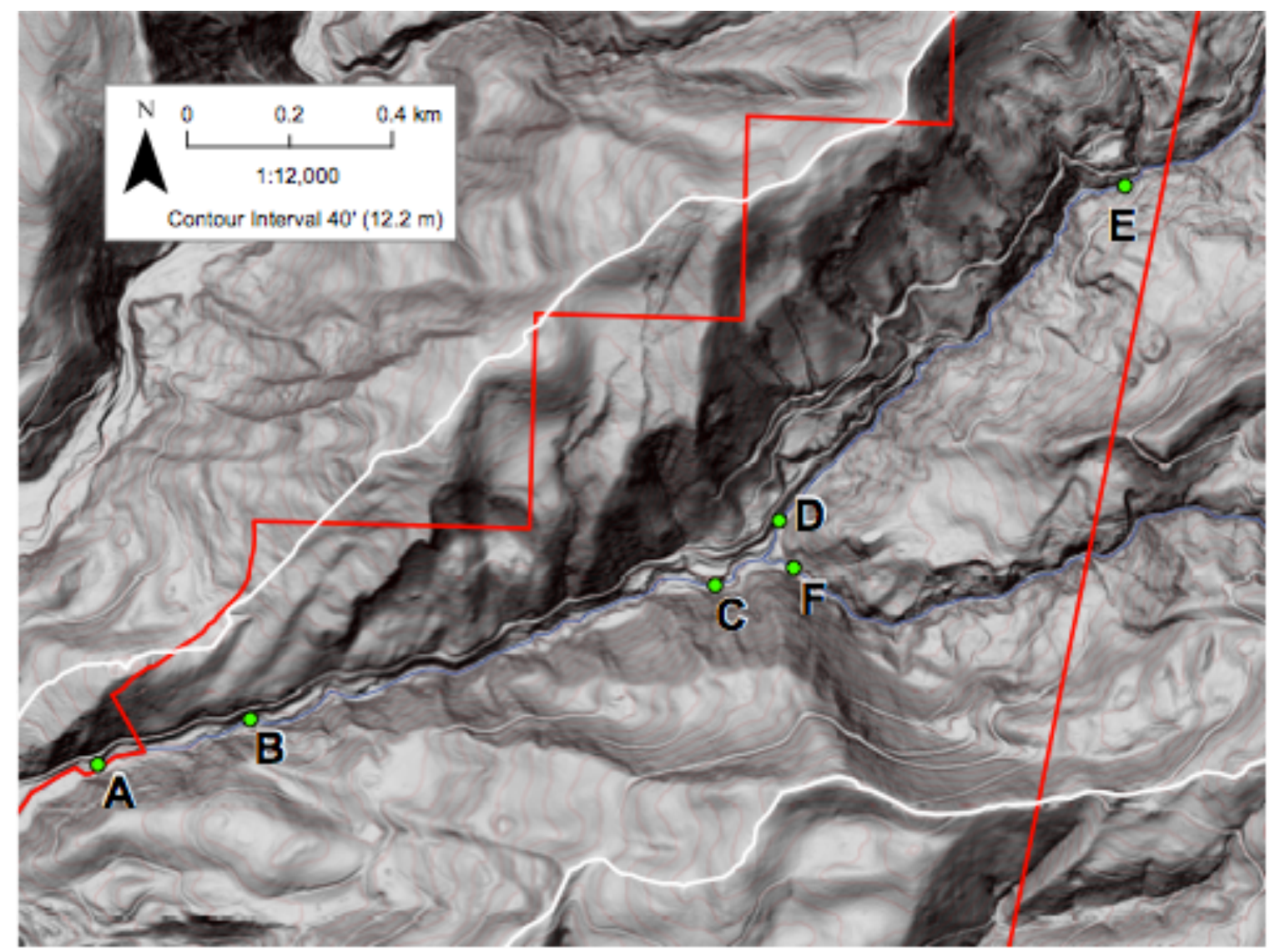

Figure 8 - Cross-section benchmarks used for referencing stream reach sections

By measuring slope distance between the cross sections (known location) and the

closest rebar stake using a cloth tape, the location of the GPS points could be adjusted in GIS to more accurately represent the true location of the reaches. The slope distance from rebar stakes $6,26,28,61$, and 63 to landscape features recognizable in GIS such as tributaries and bridges were also recorded in the third survey to further improve GPS point accuracy.

\section{Survey 4}

Survey 4 was conducted in November 2013 with the goal of collecting tree height and $\mathrm{DBH}$ data on the dominant and co-dominant population of red alder in Little Creek. DBH and height data was collected on 30 red alder throughout the study area using a 
laser range finder and diameter tape. Representative trees of dominant and co-dominant red alder within each reach were measured.

An increment borer was used to take core samples at DBH of representative trees within each diameter class, and winter growth rings were counted using a magnifying glass. Larger cores were more difficult to analyze and some samples were too difficult to age with confidence. Both sanding and application of water were used to increase visibility of growth rings on more difficult tree cores. Attempts were not all successful and several samples were discarded due to lack of confidence.

A separate attempt at aging was made using a chainsaw to cut cross-sections from two red alder that had toppled since the fire. Only two cross-section samples were collected as a test in order to assess the function of this aging method. Cross-section samples were sanded smooth using 120 grit sandpaper and an electric sander. One sample was successfully aged through a ring count, but the other sample had deteriorated around the edges and could not be aged with confidence. After samples were analyzed, it was determined that the method may work to age other red alder in Little Creek, but the time and disturbance level associated with felling stumps in the riparian zone was beyond the scope of this study. Using the age vs. DBH regression equation paired with the timing of the last large disturbance (1955 debris torrent) generated satisfactory estimates of age for this study.

\subsection{Red Alder Large Woody Debris}

An estimation of the volume of red alder LWD contributed to the Little Creek watershed following the fire was calculated by applying mortality data to Smalian's Formula (MFLNRO, 2011). Smalian's formula is a basic log scaling formula applied to 
log sections that have been bucked into shorter lengths with minimum taper. Smalian's formula over estimates standing tree volumes because a standing tree significantly tapers from the base to the apex. However, Smalian's formula was used for this study in order to provide an efficient and consistent means for comparing LWD volume calculated in 2010 (Smith, 2010), which also utilized Smalian's formula. LWD volumes in this study are intended to produce rough estimations. Recommendations regarding the use of more accurate volume equations are made in the conclusion and recommendations section.

The average volume per red alder was determined based on field measurements and then applied to the mortality data to produce an estimate of LWD volume per reach. Values were compared to a senior project LWD survey, which utilized the same volume equation and was conducted in 2010, before red alder started showing signs of mortality (Smith, 2010). The comparison allows for an approximation of the volume of red alder LWD contributed since 2010.

\subsection{Assumptions for Red Alder LWD Volume Calculation}

1. Red alder experiencing mortality after the fire have relatively the same DBH and height

2. Red alder diameter becomes less than $7.62 \mathrm{~cm}$ ( 3 in) approximately 5 feet from the apex of the tree. Therefore, subtracting 5 feet from the average red alder height value produces a reasonable estimate of length in Smalian's formula (Figure 9).

3. All red alder experiencing mortality following the fire will topple within the flood prone area of Little Creek

4. DBH and 3 in will be used in calculating $A_{1}$ and $A_{2}$ in Smalian's formula. The stump and root wad associated with each red alder will also contribute to LWD, but a rough estimation is desired. 


\subsection{Smalian's Formula}

Smalian's formula calculates the volume of a log on the basis of a parabolic frustum. The formula requires measurements of two diameters and the length.

$$
V=\left(\frac{A_{1}+A_{2}}{2}\right) L
$$

Where: $\quad \mathrm{V}$ is the volume of the $\log$ in cubic meters

$A_{1}$ is the area of the small end of the log in square meters

$\mathrm{A}_{2}$ is the area of the large end of the log in square meters

$\mathrm{L}$ is the length of the log in meters

Figure 9 - Smalian's Formula from the Ministry of Forests, Lands and NRO 2011 


\section{CHAPTER 5}

Analysis

This chapter contains data collected during four red alder mortality surveys and a statistical analysis of red alder mortality in Little Creek. The data set consists of population, mortality, DBH, height, and age of selected red alder from reaches 1-66 along with photographs and field notes regarding fire severity.

\subsection{Population \& Mortality Distribution}

A total of 580 red alder were observed in the 2.16 kilometers of Little Creek surveyed. Reaches 0-20 make up the non-burn zone. Reaches 21-66 are within the burnzone. The burn zone was determined based on scorch marks of upland vegetation visible from the stream channel. Low severity is defined by scorch marks on upland vegetation less than 3 meters $(10 \mathrm{ft})$, but no evidence of the fire reaching the stream channel. Medium severity is defined by scorch marks of upland vegetation greater than 3 meters $(10 \mathrm{ft})$ and evidence of the fire reaching the stream channel. A box plot of the proportion of dead red alder vs. in or out of the burn zone illustrates a larger proportion of dead red alder within the burn zone (figure 10). 


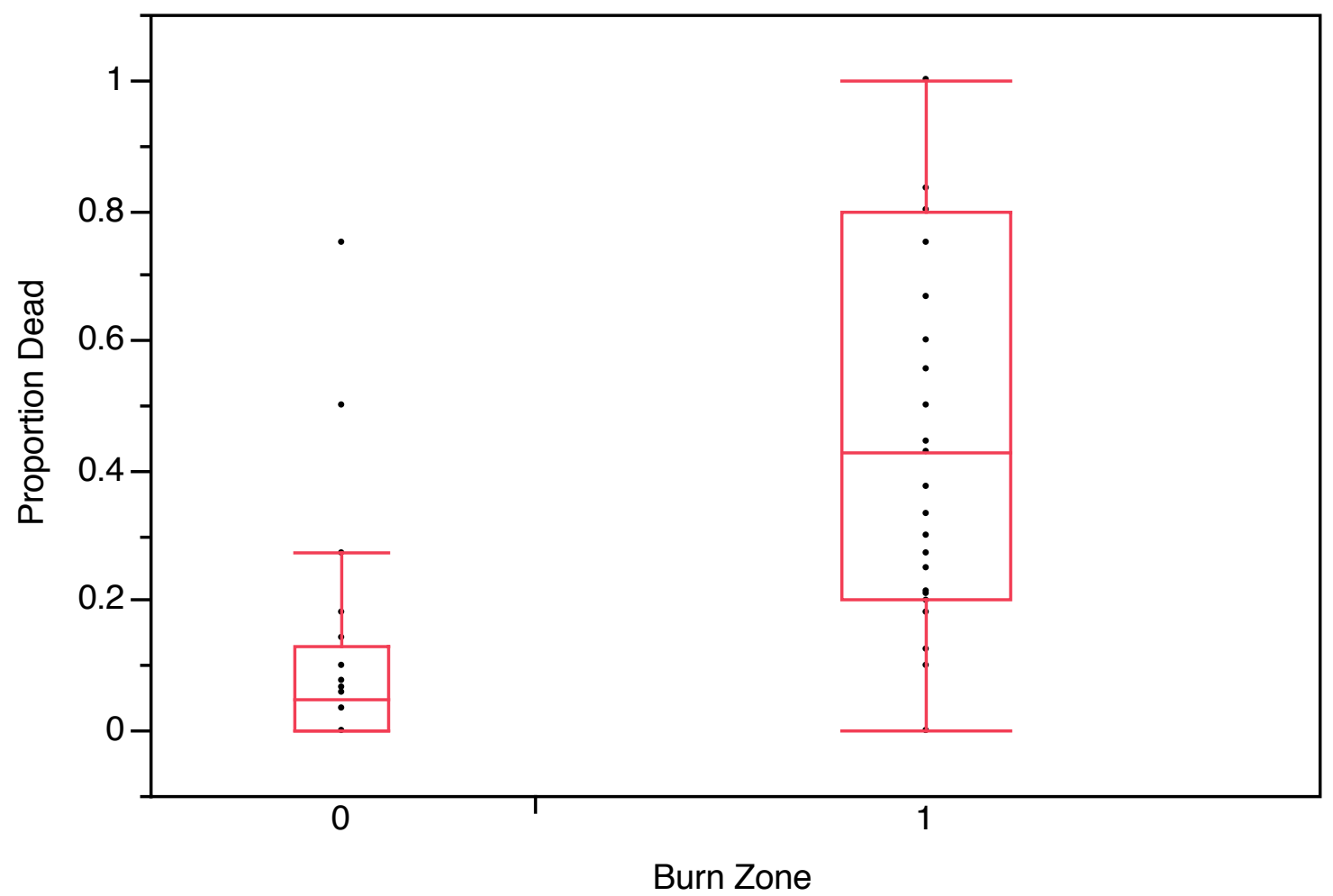

Figure 10 - Proportion of dead red alder verses in/out of the burn zone.

The non-burn zone and burn zone are coded as 0 and 1 respectively in (figure 10).

The mean proportion of dead red alder in the non-burn zone and burn-zone is .11 and .45

respectively (Table 3). Dead red alder within the non-burn zone could be explained

windthrow or other causes associated with weathering and time.

Table 3 - Proportion of dead red alder in and out of the burn zone

Mean

Std Dev

Std Err Mean

Upper 95\% Mean

Lower 95\% Mean

Sample Size
Non-Burn Zone

0.11

0.19

0.04

0.20

0.02

20
Burn Zone

0.45

0.34

0.05

0.56

0.34

42 
Figure 11 shows the proportion of dead red alder vs. live red alder on a reach-byreach basis. White and black bars in figure 11 represent live and dead red alder respectively. Total bar height represents total red alder population within each reach. The black line represents a longitudinal profile of Little Creek derived in GIS from a 2011 LiDAR based digital elevation model (DEM).

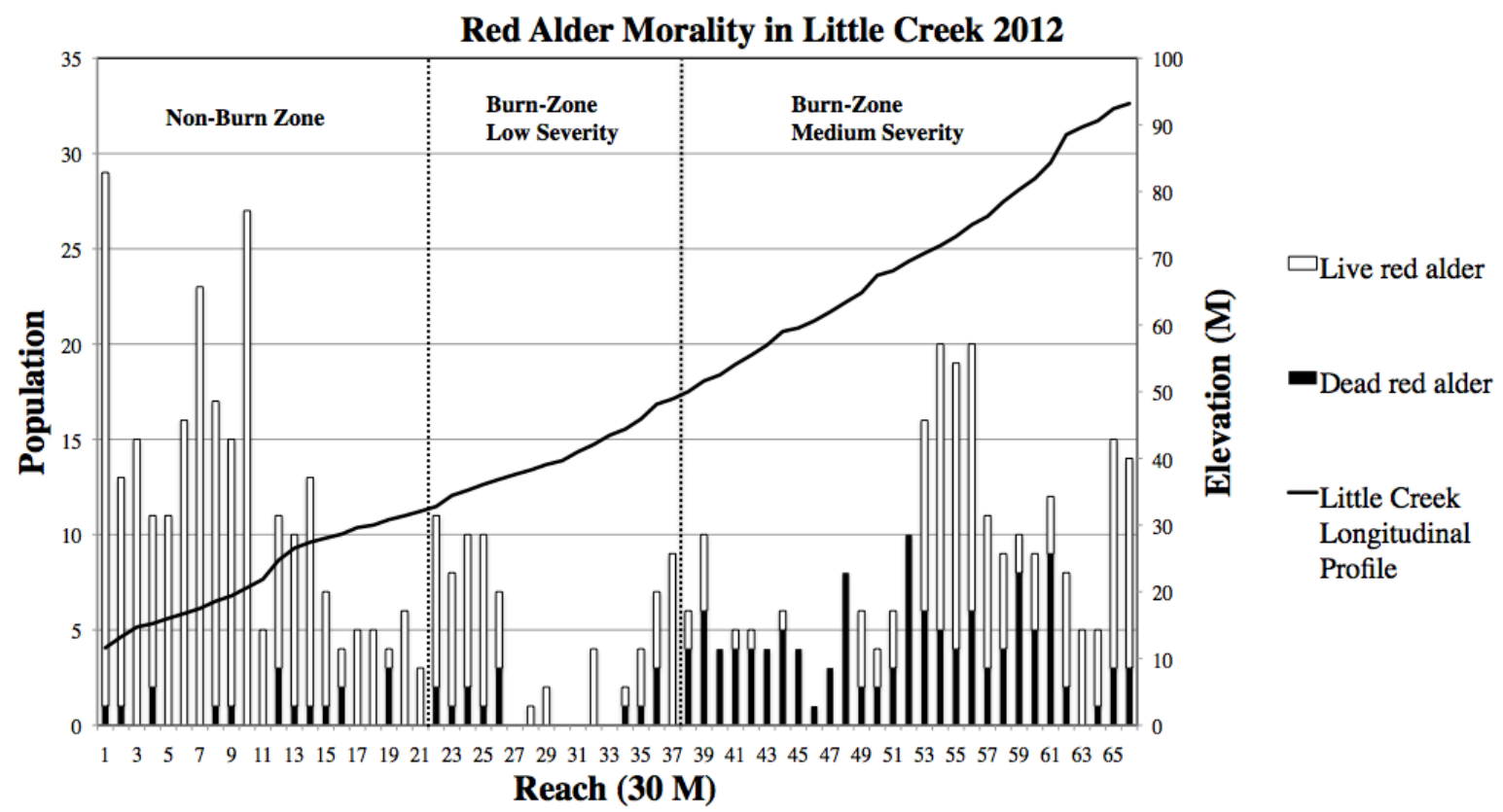

Figure 11 - Red alder mortality in Little Creek.

Of the 250 red alder in the non-burn zone, $7 \%$ were dead. Of the 75 red alder in the low severity burn zone, $18 \%$ were dead. Of the 264 red alder in the medium severity burn zone, $46 \%$ were dead. However, not all mortalities can be considered a direct result of the fire.

Red alder populations were greatest at the confluences of Little Creek and Scotts Creek and the North and South forks of Little Creek. Greater populations near the confluences are likely a result of a higher frequency of disturbances leading to exposed mineral soil. Reaches 27, 30, 31, and 33 did not contain red alder. Reaches with no red 
alder could be explained by several bedrock outcroppings within Little Creek, which result in poor habitat conditions for red alder seedlings. The average number of red alder per reach was approximately 9 with a range of $0-29$. The greatest proportion of red alder mortality occurred between reaches 38 and 48 . Reaches 40, 43, 45-48, and 52 experienced $100 \%$ red alder mortality. The largest population of red alder was 29 and occurred in reach 0, at the confluence of Little Creek and Scotts Creek.

Diameter at breast height was collected on 128 of the surveyed trees during the first survey and 29 trees during the fourth survey. Mean DBH was $44 \mathrm{~cm}$ (17 in) and 36 cm (14.5 in) respectively. Mean DBH of dead red alder in Little Creek was $45.69 \mathrm{~cm}$ (17.98 in) (Figure 12). The two outliers in figure 12 with a DBH greater than $70 \mathrm{~cm}$ can be explained by an error made in data collection. Both outliers are two trees growing together that were measured as one tree during the first survey (Figure 12).

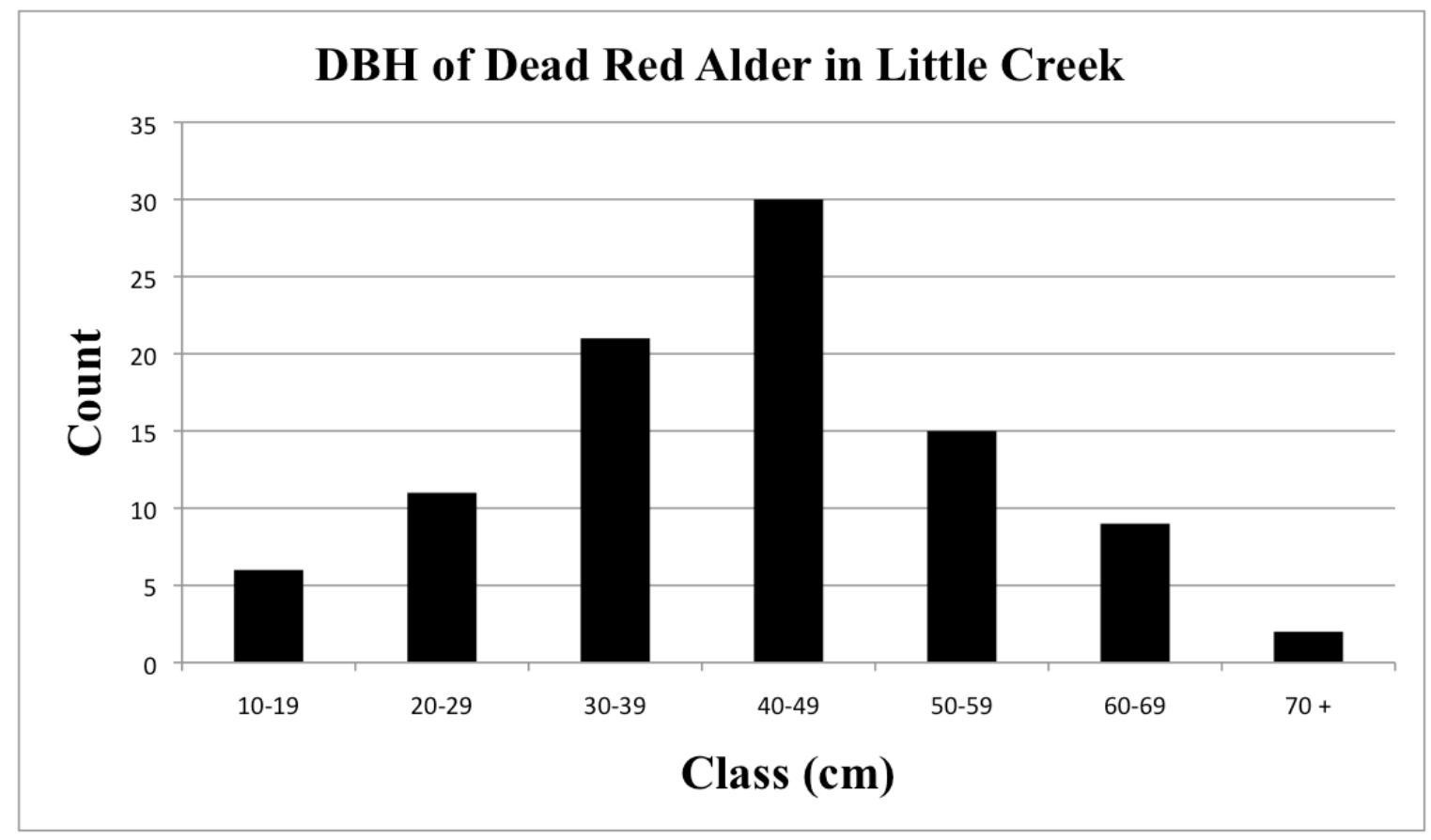

Figure 12 - DBH of dead red alder in Little Creek (Hardy, 2012). 
Thirteen red alder were aged using an increment borer at breast height $1.37 \mathrm{~m}(4.5$ $\mathrm{ft})$. One red alder with a DBH of $46.99 \mathrm{~cm}$ (18.5 in) was aged using a cross-section cut at stump height and sanded smooth. A regression of age and $\mathrm{DBH}$ produced an R-squared value of .76 (Figure 13). With 95\% confidence, the mean age of dead red alder in Little Creek with a DBH of $45.69 \mathrm{~cm}$ (17.98 in) is between 29 to 38 years old. However, the sample size was only 13 out of 580, and large variation exists within each DBH class, so the regression equation should not be used if precise estimations are desired.

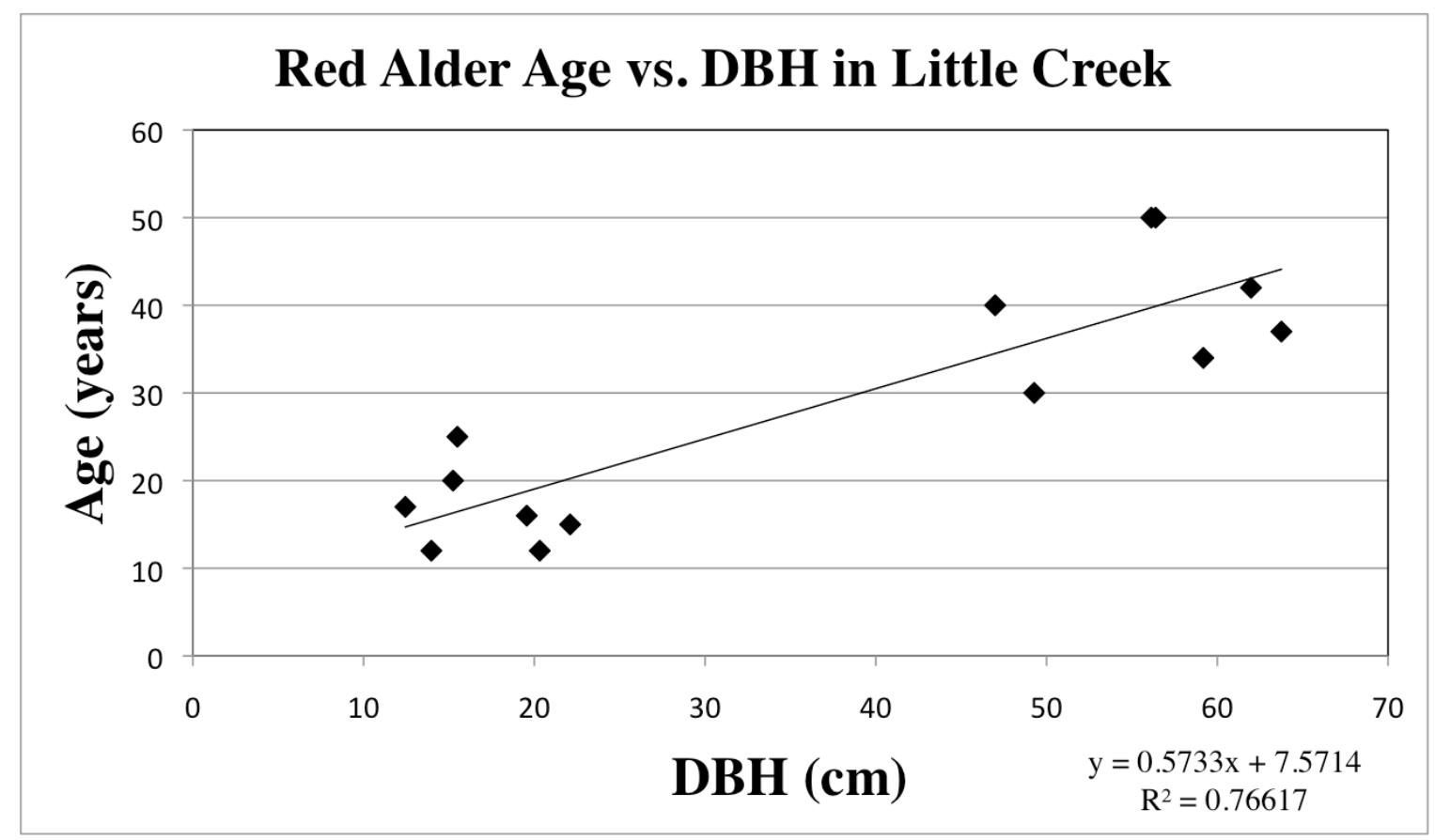

Figure 13 - Red alder age vs. DBH.

During the fourth survey, height was collected using a laser rangefinder on 29 red alder representing each dominant and co-dominant population within individual reaches (Figure 14). Tree heights were collected starting at the Main Stem flume (Reach 12, Swanton Rd) and ending at the confluence of the North and South forks (reach 66). Height was not collected on many of the dominant stand of red alder above reach 38 because most had toppled since the fire. 


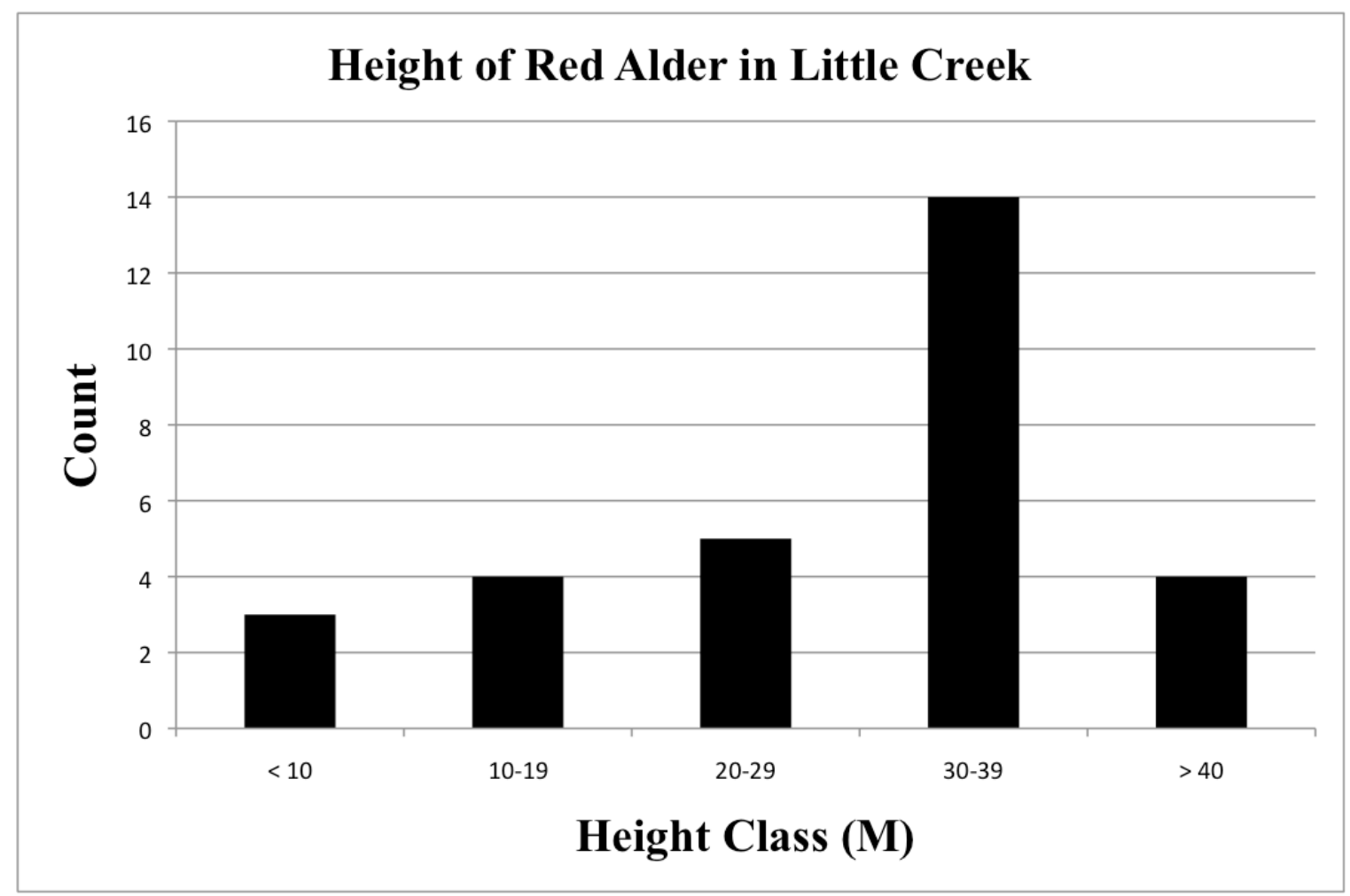

Figure 14 - Red alder tree heights in Little Creek from Survey Four (2013).

The maximum height observed was 40.8 meters $(134 \mathrm{ft})$. The shortest age class of red alder measured was 6 meters $(20 \mathrm{ft})$ and had a DBH of $5.08 \mathrm{~cm}(2 \mathrm{in})$. Mean height of the dominant stand of red alder was 33.7 meters $(110.8 \mathrm{ft})$. Mean height of the younger age class of red alder was 10 meters ( $34 \mathrm{ft})$. The youngest age classes of red alder were not measured i.e. red alder sprouting after the fire. A regression of red alder heights and DBH produced an R-square value of 0.62 (figure 15). Summary tables of red alder population and dimensions can be seen in (Table 4) and (Table 5). 


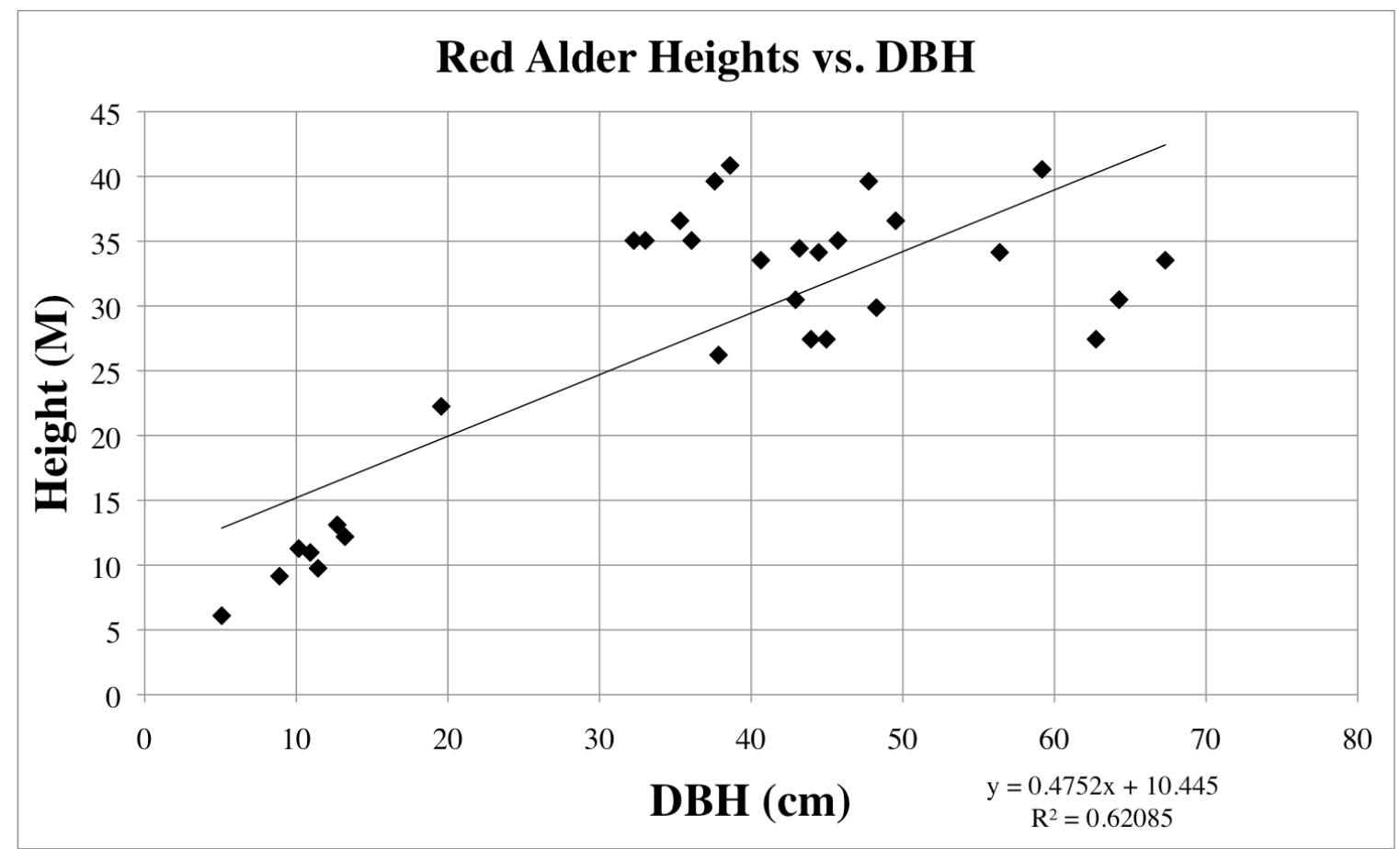

Figure 15 - Red alder heights (m) and DBH (cm) collected during survey four (2013).

Table 4 - Summary of red alder mortality

\begin{tabular}{|c|c|c|c|c|}
\hline & Non-burn zone & $\begin{array}{c}\text { Burn-zone low } \\
\text { severity }\end{array}$ & $\begin{array}{c}\text { Burn-zone } \\
\text { medium } \\
\text { severity }\end{array}$ & Total \\
\hline Reaches & $1-20$ & $21-37$ & $37-66$ & 66 \\
\hline Live & 224 & 61 & 141 & 426 \\
\hline Dead & 17 & 14 & 123 & 154 \\
\hline
\end{tabular}


Table 5 - Summary of red alder dimensions

\begin{tabular}{|c|c|}
\hline $\begin{array}{c}\text { Mean DBH } \\
\text { dead } \\
\mathbf{N}=\mathbf{1 2 8}\end{array}$ & $\begin{array}{c}45.69 \mathrm{~cm} \\
(17.99 \mathrm{in})\end{array}$ \\
\hline $\begin{array}{c}\text { Mean Height } \\
\text { Dominant } \\
\mathbf{N}=\mathbf{2 3}\end{array}$ & $\begin{array}{c}33.7 \mathrm{~m} \\
(110.8 \mathrm{ft})\end{array}$ \\
\hline $\begin{array}{c}\text { Mean height } \\
\text { Co-dominant }\end{array}$ & $10 \mathrm{~m}$ \\
$\mathbf{N}=\mathbf{7}$ & $(34 \mathrm{ft})$ \\
\hline
\end{tabular}

\subsection{Red alder LWD Recruitment in Little Creek}

The average red alder experiencing mortality following the Lockheed Fire had a DBH of $45.69 \mathrm{~cm}$ (17.99 in) and a height of approximately 33.5 meters (110 ft). Using 45.69 for $A_{1}, 7.62$ for $A_{2}$, and 32 meters for length in Smalian's formula produces a volume of $2.69 \mathrm{~m}^{3}\left(95.21 \mathrm{ft}^{3}\right)$ per red alder. Given the assumptions listed in Chapter 3, a total of $362.42 \mathrm{~m}^{3}\left(12,798.70 \mathrm{ft}^{3}\right)$ of red alder LWD is associated with the Lockheed Fire, an increase of approximately $245 \%$ from the (Smith, 2010) LWD survey (Table 6). Applying the average red alder volume to the population and mortality data produces (Figure 16). 
Table 6 - Summary table of red alder LWD volume in Little Creek Reaches 1-66.

\begin{tabular}{|c|c|c|c|c|}
\hline $\begin{array}{c}\text { 2010 } \\
\text { Total volume of red } \\
\text { alder LWD in } \\
\text { effective and } \\
\text { potential Zone } \\
\text { (Smith, 2010) } \\
\left(\mathbf{m}^{3}\right)\end{array}$ & $\begin{array}{c}\text { Non-burn } \\
\text { zone }\end{array}$ & $\begin{array}{c}\text { Burn-zone } \\
\text { low severity }\end{array}$ & $\begin{array}{c}\text { Burn-zone } \\
\text { medium } \\
\text { severity }\end{array}$ & Total \\
\hline $\begin{array}{c}\mathbf{2 0 1 3} \\
\begin{array}{c}\text { Estimated total } \\
\text { volume of red alder } \\
\text { LWD contributed } \\
\text { since 2010 } \\
\left(\mathbf{m}^{3}\right)\end{array}\end{array}$ & 40.00 & 32.95 & 77.57 & 147.88 \\
\hline
\end{tabular}

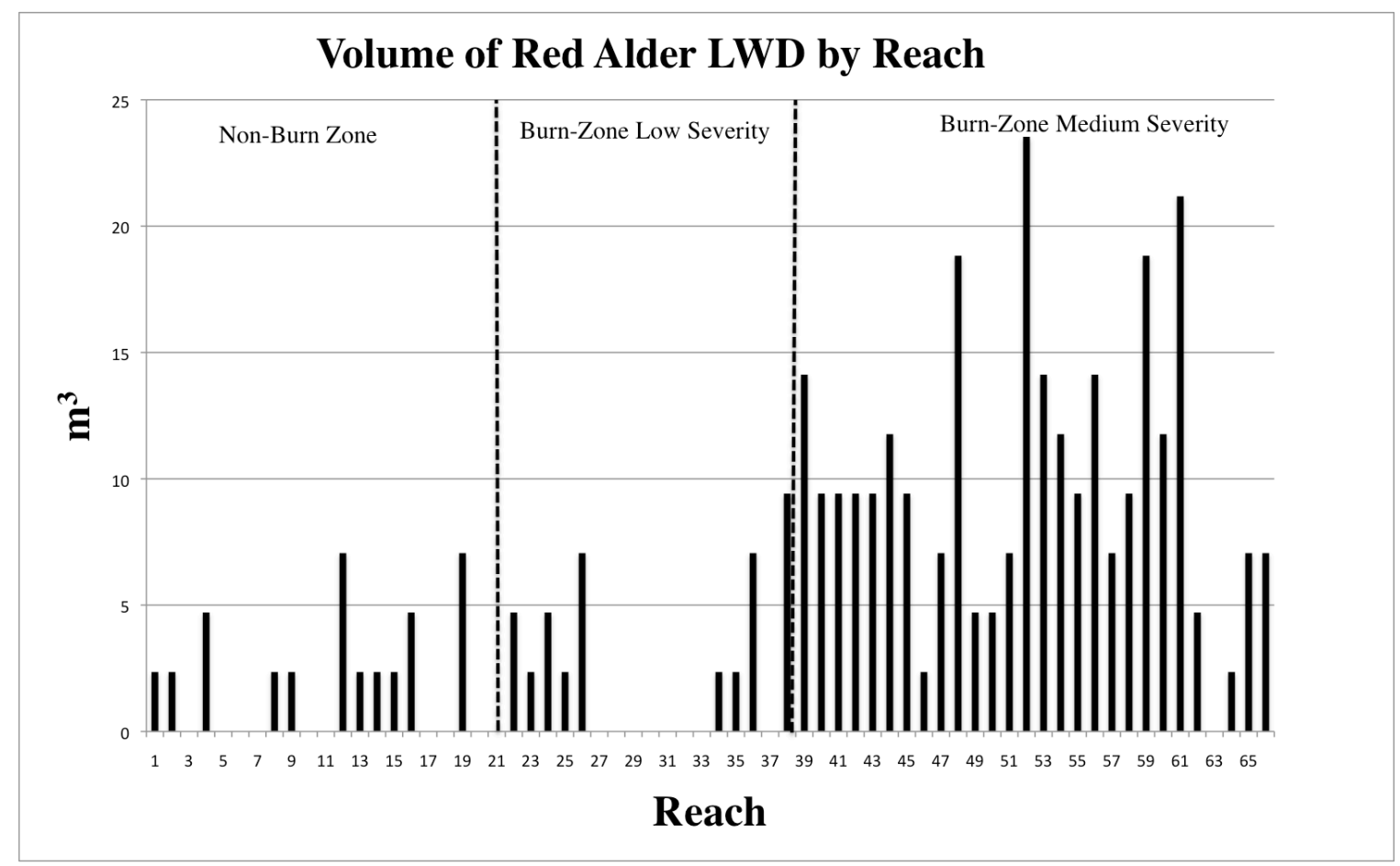

Figure 16 - Volume of recruited red alder LWD from 2010 - 2013. 


\subsection{Spatial Characteristics of the Lockheed Fire in the Riparian Zone}

The burn zone begins at reach 21 and continues past the end of the study area. A distinction is made between burn severity in reaches 21-37 and 37-66. Reaches 21-37 experienced low fire severity as reflected in scorch mark heights of upslope vegetation less than $10 \mathrm{ft}$ and lack of evidence of the fire reaching the stream channel. Reaches 3765 experienced medium burn severity as reflected in scorch height marks of upland vegetation greater than $10 \mathrm{ft}$ and evidence of the fire reaching the stream channel.

Reaches 41-48 experienced the highest burn severity and greatest red alder mortality out of the entire surveyed portion of Little Creek. Evidence of burn severity is reflected in scorch height marks on upland vegetation, reduced overstory canopy as a result of the fire, red alder mortality, and abundance of understory vegetation sprouting after the fire (Figure 17). 


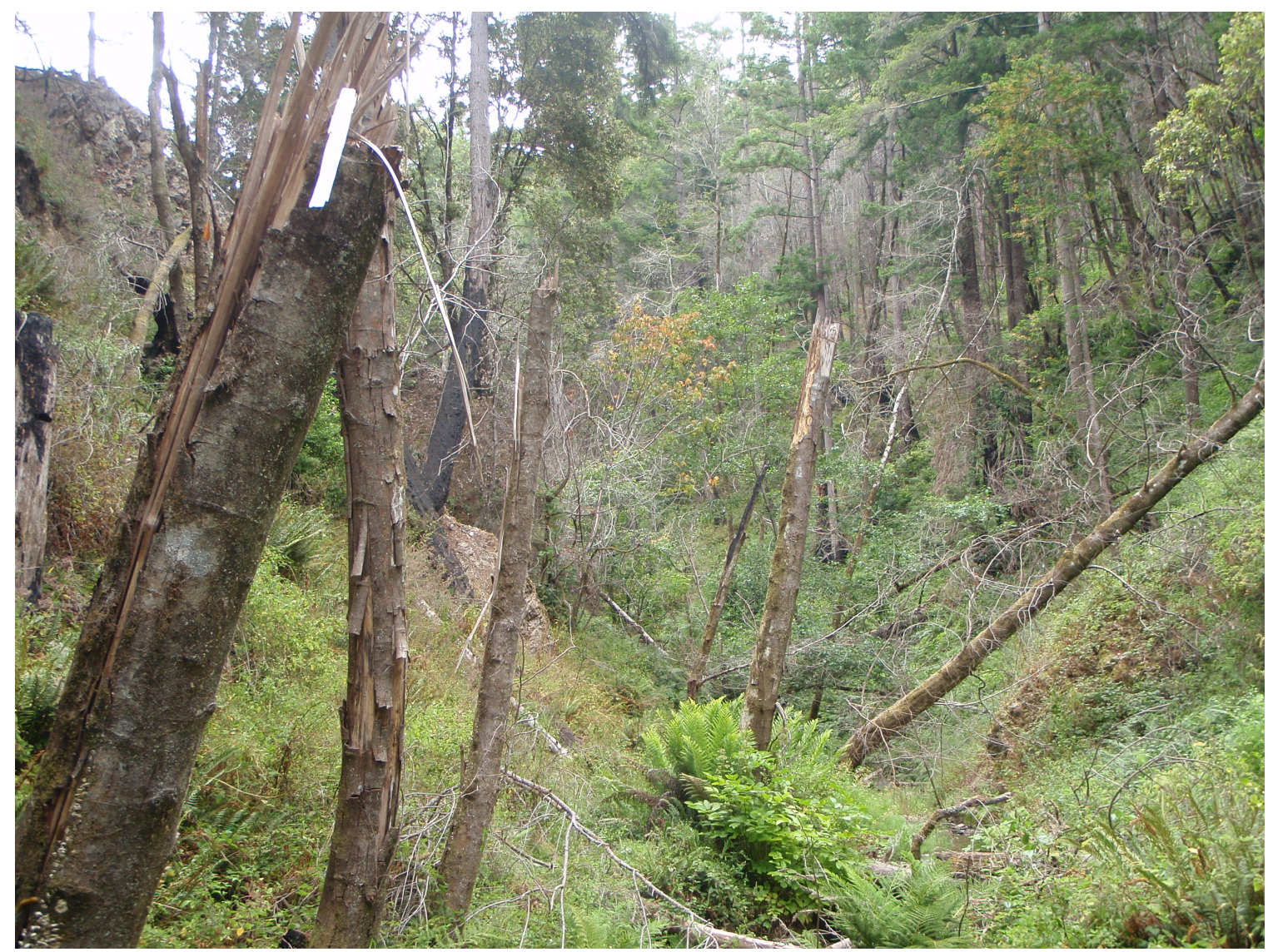

Figure 17 - Top of reach 38 looking upstream (Survey Three 2012).

The Lockheed Fire ignited on the west side of the upper Scotts Creek watershed along Buttencourt Gulch, and driven by southerly winds, quickly spread from side slope to side slope throughout the watershed (Figure 18) toward Little Creek. After burning the ridgelines, the fire slowly back burned downslope toward the Little Creek stream channels starting above the confluence of the North and South Fork. After 48 hours, the fire had burned into the Little Creek riparian zone (Brian Dietterick pers. Comm.) The Little Creek watershed is steep and narrow and divided into a North and South Fork by a well-defined ridge approximately $2.16 \mathrm{~km}$ up from the confluence with Scotts Creek. The southerly winds and physical characteristics of the watershed resulted in higher burn severity upslope of reaches 40-60. The wind-driven fire conditions and steepness of the side slopes may have been a factor in greater red alder mortality between reaches 41-48. 


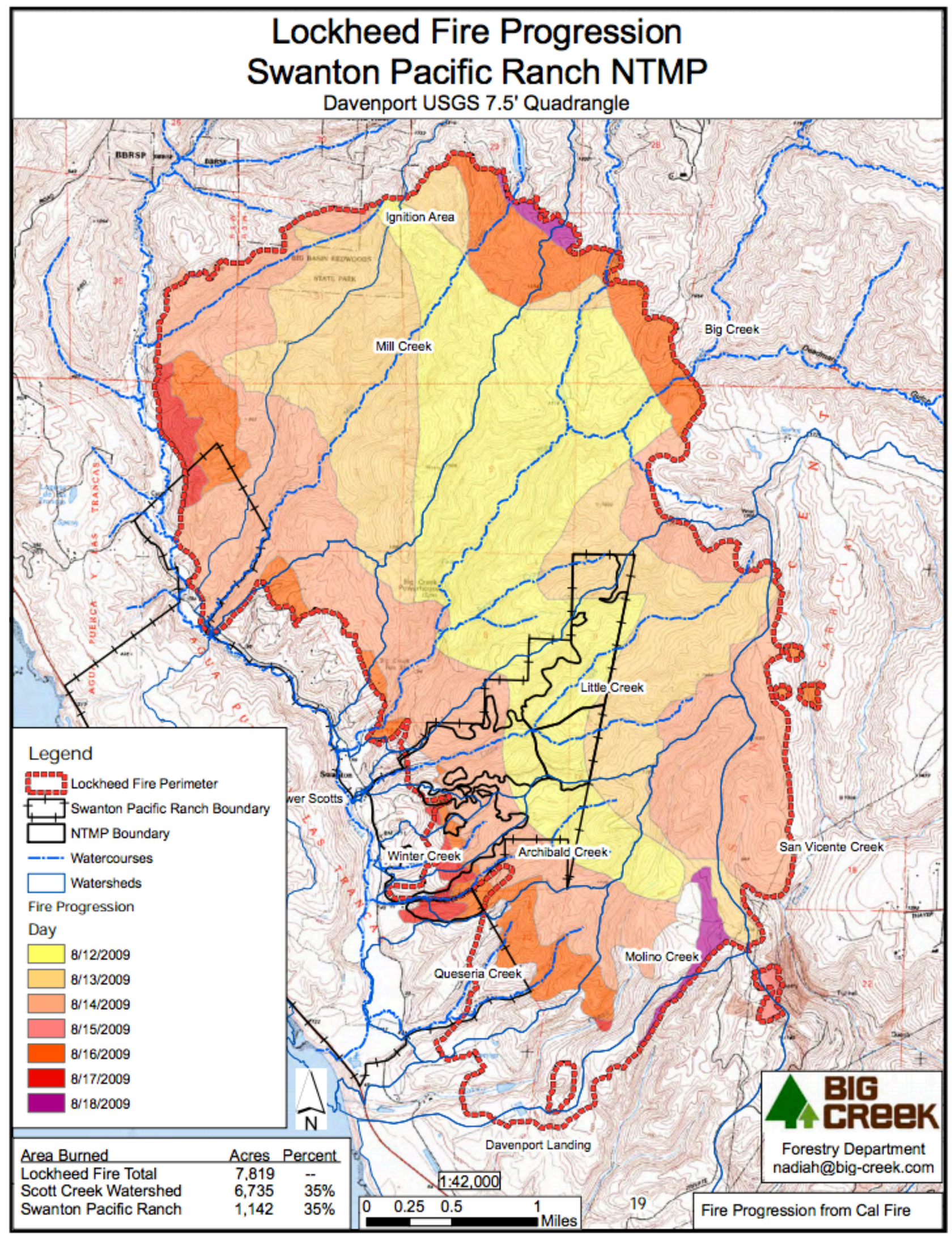

Figure 18 - Lockheed Fire progression from Cal Fire 


\subsection{Statistical Analysis}

Logistic regression was used in the statistical analysis in order to predict red alder mortality. The study design was observational, so statistical significance from this test can only be used to show association between the predictor variables and red alder mortality, not cause and effect. The statistics package JMP Pro 10 was used for all statistical analysis.

The predictor variables burn zone (in/out), reach (1-66), reach ${ }^{2}$, reach*burn zone, and reach $^{2 *}$ burn zone were tested for significance. Burn zone was designated as reaches 21-66 and coded as a 0 or 1.

Burn zone and reach both proved to be associated with red alder mortality at the .05 significance level. A graph of the probability of live red alder compared to reach showed the probability of live red alder was high at the confluence of Scotts Creek, decreased entering the burn zone, and increased near the confluence of the North and South Forks (Figure 19). Reaches 37-50 had the highest burn severity based on field notes and photographs and also lowest probability of surviving based on this model. There was a quadratic effect as the distance increased on either side of reach 44 (Figure 19). A linear trend line is useful in illustrating the difference in slope between the nonburn-zone and burn-zone i.e. the probability of survival changes whether trees are in or out of the burn zone (Figure 20). 


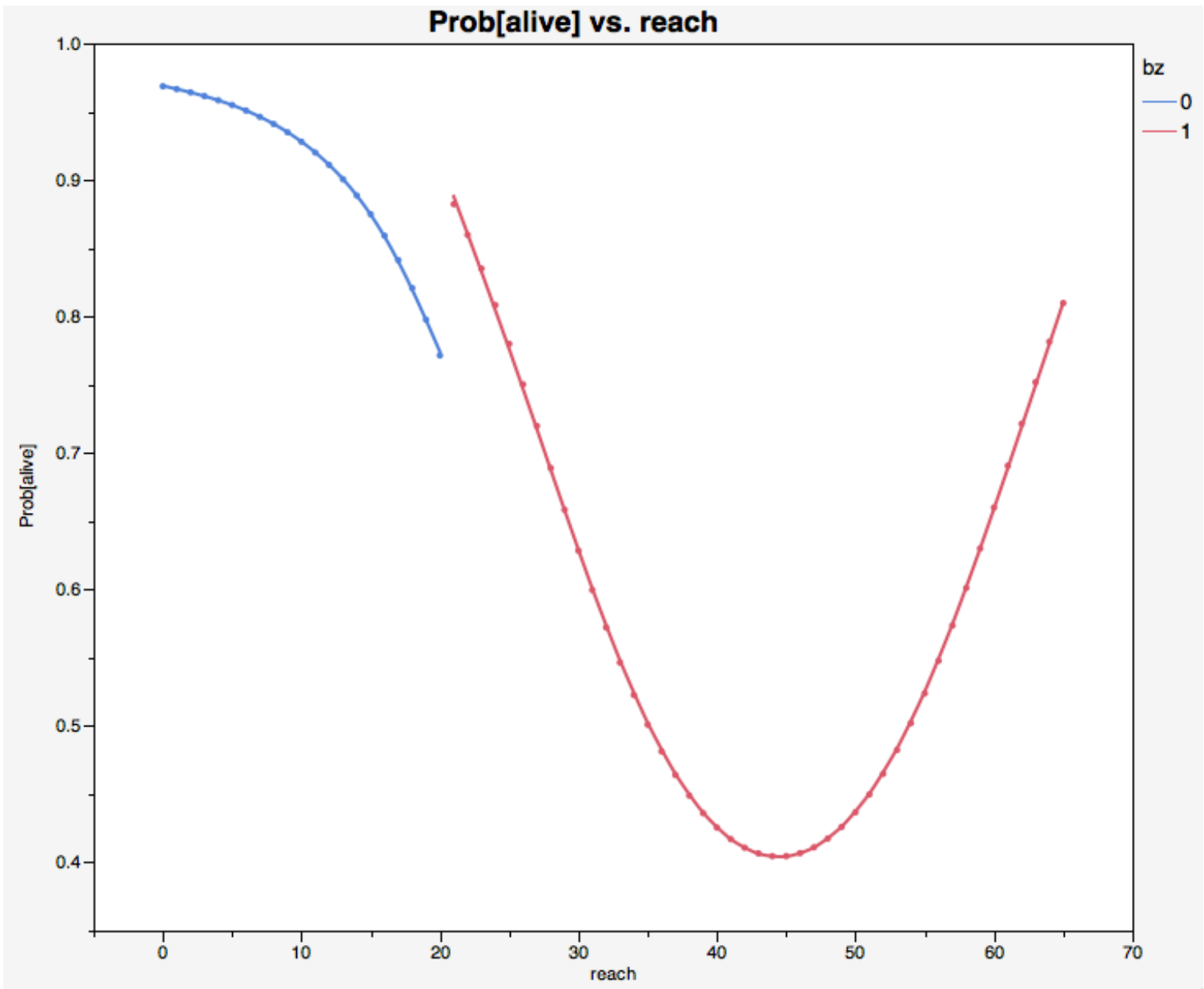

Figure 19 - Probability of being alive vs. reach. 


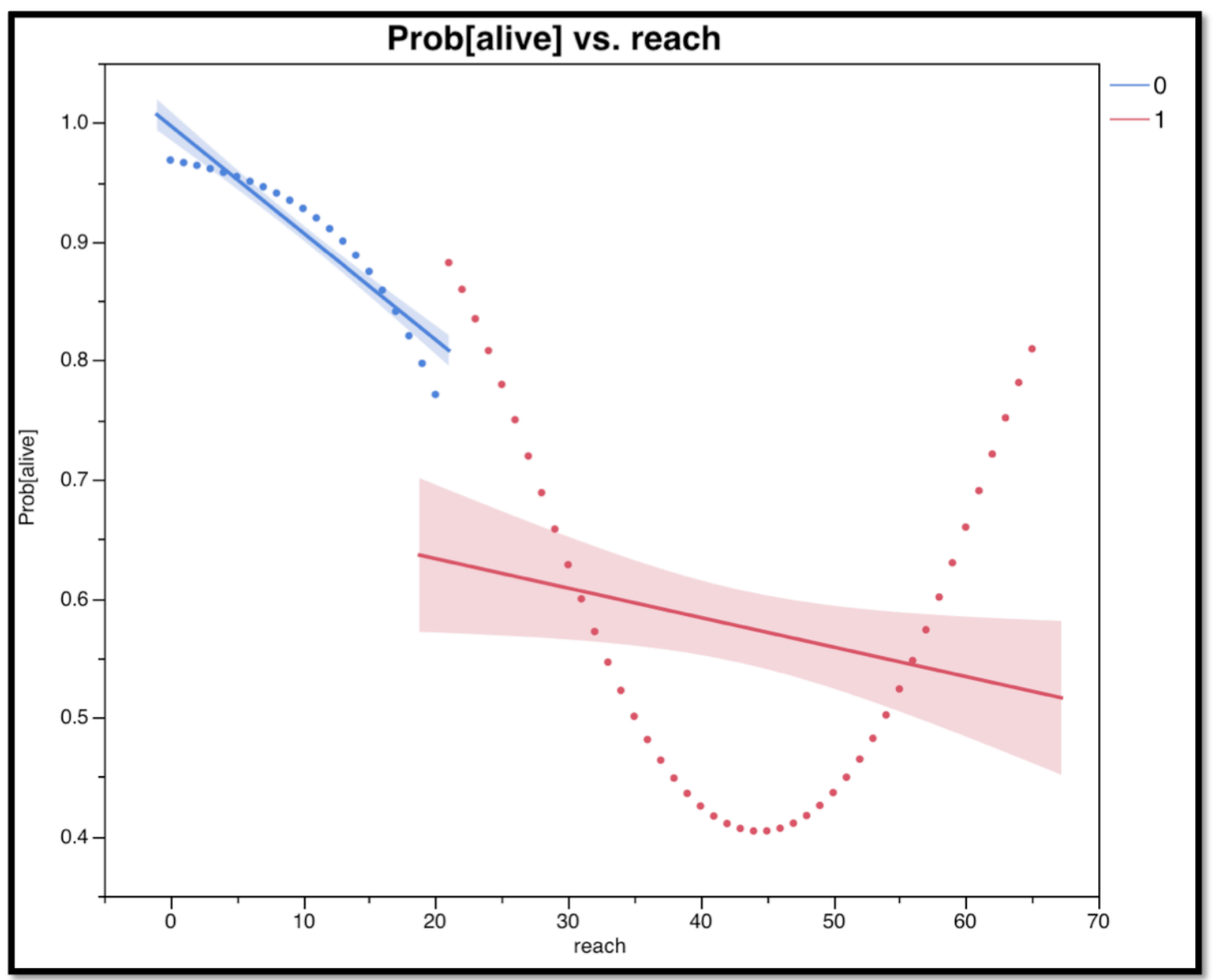

Figure 20 - Linear model of probability vs. reach.

Key findings from the statistical analysis were the probability of survival depended on reach location and the survival rate changed at a different rate in/out of the burn zone. According to the logistic regression performed, red alder in the burn zone were 9.7 times more likely to be categorized as dead than trees located in the non-burn zone. However, this is an oversimplified model that may not be a good representation of the many ecosystem processes at work leading to red alder mortality. This model only shows two variables associated with red alder mortality not direct causation. Some other factor not accounted for in the model could help to explain further why there is an accelerated rate of red alder mortality within the burn zone. 


\section{CHAPTER 6}

\section{Discussion}

This chapter interprets the data collected throughout the four surveys of red alder mortality in Little Creek. Timing of the Lockheed Fire, and age of red alder in relation to mortality are discussed as well as the potential influences of red alder mortality on the Little Creek watershed such as temporarily reduced riparian canopy and the introduction of LWD.

\subsection{Timing}

Time of year is an important factor in how the Lockheed Fire influenced red alder mortality in Little Creek. The fire spanned Little Creek, and began back burning into the riparian zone within 48 hours after ignition. Red alder in Little Creek were near the height of foliar production or beginning to slow down in preparation for fall. The trees likely had produced buds that would stay dormant until the following spring. The buds were located in the canopy, approximately 20 meters above the forest floor. Fire back burned into the riparian zone along the ground and most significantly influenced red alder in close proximity to reach 44 . Fire in the riparian zone was extinguished within a short time without intervention from fire crews besides a minor effort approximately $610 \mathrm{~m}$ (2000 ft) upstream from the confluence with Scotts Creek.

During the first spring after the fire (2010), the red alder canopy produced leaves, but the distribution of energy was likely disrupted. The fire may have damaged the cambium of red alder. Phloem, which carries nutrients throughout vascular plants, may have been significantly stressed from heat generated by the fire. Energy was being produced in the canopy, but not distributed down to the root system. Without proper 
distribution of nutrients, red alder were no longer able to sustain normal biological processes. The fire may have essentially girdled red alder, eventually resulting in mortality. This likely best explains why red alder in Little Creek first appeared to have survived the Lockheed Fire, but then experienced second-year mortality.

Not all red alder experiencing mortality after the fire had fire scars directly on the bole of the tree. Damaged cambium may explain some red alder mortality, but another possibility could be damaged root systems. The fire burned on the ground over several days and was smoldering in the riparian zone of Little Creek. Red alder have relatively shallow root systems where water is available, and fire burning on the ground may have burned the roots. Burned root systems would almost certainly result in mortality.

A possible similarity exists to the Harrington (1984) study where 4-year-old planted red alder in Oregon and Washington were cut at five stump heights $(0,10,30,50$, and $70 \mathrm{~cm}$ ) during 4 different months out of the year (January, May, July, and September). The number of stumps surviving was greatest in January at $30 \mathrm{~cm}$ and lowest at 0 and $10 \mathrm{~cm}$ cut during July and September. Plots cut in July experienced far more $2^{\text {nd }}$ year mortality than the other months (Harrington, 1984). Although the study conducted an experiment utilizing cutting as a disturbance instead of fire, there are similarities between timing and mortality rates. Plots cut in July experienced $2^{\text {nd }}$ year mortality and the Lockheed Fire occurred on August $12^{\text {th }}$ and also resulted in $2^{\text {nd }}$ year mortality. Age was also an important factor in red alder mortality in Little Creek.

\subsection{Age of Red Alder in Little Creek}

Senescence is the progression of cells losing the ability to divide over time, eventually leading to a shutdown of the necessary biological processes for survival, essentially the physiological process of growing old. With $95 \%$ confidence, the mean 
age of dead red alder in Little Creek with a DBH of $45.69 \mathrm{~cm}$ is between 29 to 38 years old. However, using time since the 1955 debris torrent to predict the age of the dominant stand of red alder produces a value closer to 54 years old at the time of the fire. The maximum life span of red alder is approximately 100 years, with the average red alder reaching maturity at 60-70 years old (Worthington et al. 1962). Mature red alder do not respond as well to disturbance as younger red alder according to Harrington (1984), and the fire may have been enough to push the dominant stand of red alder into a terminal condition.

\subsection{Influence of Red Alder Mortality on the Little Creek Watershed}

Riparian vegetation contributes to the regulation of microclimates around stream channels by generating shade and blocking wind. Before the Lockheed Fire, the dominant stand of red alder in Little Creek provided significant canopy cover from the confluence of Scotts Creek to the confluence of the North and South forks (reaches 1-66). Since the fire, many of the dominant red alder in the burn zone have toppled allowing more sunlight to reach the stream channel. Red alder mortality was most significant in reaches 38-59. Consumption of overstory canopy and understory vegetation by the fire in reaches 38-59 along with increased light reaching the riparian zone has generated an influx of pioneer species including red alder. These species will likely dominate reaches 38-59 until the epicormic sprouts of trees damaged in the fire and capable of regrowth become the dominate vegetation class and reduce the amount of sunlight reaching the understory. Red alder sprouting immediately after the fire will likely survive given the temporarily increased space in the canopy. Understory vegetation will be more vigorous in stream reaches with increased fire severity. 
Stream temperature during summer months may also have been temporarily influenced by a reduction in canopy. However, given the steep and narrow shape of the Little Creek watershed and availability of water for re-sprouting vegetation, the influence on temperature will likely be short lived.

Changes in the Little Creek stream channel from 2002-2012 have been relatively small, but typically associated with the introduction of LWD (Perkins, 2012). Since the fire, increased red alder mortality has occurred and will continue to dramatically increase the recruitment of LWD. The 2010 LWD survey of Little Creek showed approximately $147.88 \mathrm{~m}^{3}$ of red alder LWD in the combined effective and potential zones of reaches 2166. An estimated $322 \mathrm{~m}^{3}$ additional red alder LWD is associated with red alder mortality following the Lockheed Fire. The specific influences of increased red alder LWD in the Little Creek watershed require further investigation. However, the introduction of LWD in Little Creek has been associated with morphological changes and is important to stream function (Perkins, 2011). These changes continue to be evaluated as part of the Little Creek Project and other studies based in the Little Creek watershed.

Historically, debris torrents associated with large storm events occurred relatively frequently in the Little Creek watershed. "The flood of 1955 repeated the pattern set by an earlier flood in 1940" (Lud McCrary, Scotts Creek Watershed Assessment). A debris torrent similar to the one in 1955 or another fire will likely occur in the future resulting in significant changes to the stream channel and riparian vegetation in Little Creek. This research will provide a baseline for which comparisons can be made in order to better understand riparian succession and hydrologic processes in Little Creek. 


\section{CHAPTER 7}

Conclusion and Recommendations

\subsection{Conclusion}

A positive association was identified between the burn zone and red alder mortality in Little Creek evident by the proportion of dead red alder within the burn zone and low probability of survival associated with the burn zone. Red alder LWD within the burn zone increased approximately $245 \%$ from the LWD survey inn 2010. A temporary decrease in riparian canopy cover along Little Creek and an influx of pioneer species has occurred within the burn zone. Vegetation is growing back quickly since the fire including red alder.

The dominant stand of red alder in Little Creek experiencing mortality after the Lockheed Fire may have been approaching the age of senescence and in a sensitive state when the fire occurred. Indications are that heat stress related to the fire was sufficient enough to cause a die off of red alder in 2011. Results indicate an association between the burn zone and red alder mortality in Little Creek, suggesting mortality was fire induced. However, this observational data does not prove causation, and some other factor, such as pathogens were not accounted for in this study and could also play a role in red alder mortality in Little Creek. Given other factors may have played a role in red alder mortality in Little Creek, the analysis reported here supports fire-induced mortality also occurred.

Red alder population and mortality data provides a baseline for understanding the influence of the Lockheed fire on red alder mortality and the Little Creek riparian zone. This information is an important contribution to the exploratory phase of research related to red alder in the Little Creek watershed. Future studies will benefit from this research 
as background information and for making comparisons to better understand riparian zone succession and red alder mortality in Little Creek.

\subsection{Recommendations}

This research was completed within a limited time frame, and many ideas relating to the study design became apparent following field data collection. The following section identifies areas for improvement and recommendations for future studies related to red alder mortality in Little Creek.

Two limiting factors in this research project are a lack of quantitative data and data related to individual trees. An interesting variable that was not explored is how proximity to the stream channel may have influenced red alder mortality. The straightline distance perpendicular to the center of the stream channel from each red alder could have been measured during one of the four surveys. This would have allowed another quantifiable variable to be analyzed in the logistic regression.

Another variable worth investigating is the influence of topography on the path of the Lockheed Fire. The fire was mainly wind driven, but the shape of the upland slopes and the incised stream channel of Little Creek likely influenced fire severity. LiDAR data paired with more field data collection may reveal how topography influenced the progression and severity of the fire.

Smailian's formula was used in estimating red alder tree volume in order to stay consistent with LWD data collected in 2010 (Smith, 2010). Smalian's formula overestimates a full tree volume because a full tree tapers more drastically than a bucked $\log$, which is what Smalian's formula is most often used for. An alternative approach could have provided a more accurate assessment of fire-induced LWD. For example, measurements could have been made along increments of the tree. Incremental 
measurements over the tree length would better account for tapper and result in more accurate estimations of post-fire LWD.

Senescence could explain why red alder in Little Creek might have been in a more sensitive physiological state at the time of the Lockheed Fire. Evidence for senescence was age of the dominant red alder stand and signs of weakness such as missing foliage and excessive leaning. A more common and accurate method of determining senescence within a tree stand is an analysis of mean annual increment versus periodic annual increment. Mean annual increment refers to the average growth rate per year a tree has gained to a specified age. Periodic annual increment describes the growth of a tree between the beginning and ending growth period. When looking at both lines on the same graph, the point where the two lines cross is referred to as the biological rotation age or age of senescence. However, this data requires repeated surveys over many years. Mean annual increment measurements were not available for this study, yet data collection could be started now if a more accurate determination of the age of senescence of red alder in Little Creek is desired.

The effects of fire on red alder have not been fully explored through scientific research. Designing an experiment similar to (Harrington, 1984), but using fire as a disturbance instead of cutting, would allow for more conclusive evidence relating to the effects of fire on red alder. This sort of experiment would require more time, sample plots, and the permission to use fire as a disturbance, but would generate more conclusive results about fire and red alder.

The influence of recent red alder mortality in the Little Creek watershed is still far from fully understood. A more detailed follow up investigation of the contribution of red alder to LWD in Little Creek would be beneficial in elucidating the effects of the fire on 
the function of the Little Creek riparian zone. Increasing the sample size for DBH, height, and age data would also help substantiate results. Observational data is useful, but more quantitative data relating to individual trees and red alder mortality would lend itself to a more robust analysis. 


\section{REFERENCES}

Agee K. James. 1993. Fire Ecology of Pacific Northwest Forests. Island Press.

Agee K. James, Wright S. Clinton, Nathan, Williamson, Mark H. Huff. 2002. Foliar moisture content of Pacific Northwest vegetation and its relation to wildland fire behavior. Forest Ecology and Management 167 (2002) 57-66.

Anderson, E. W. 1987. Riparian area definition - a view point. Rangelands 9:70. Dwire, K.A., and L.B. Kauffman. 2003. Fire and riparian ecosystems in landscapes of western USA. Forest Ecology and Management. 178: 61-74.

Bailey W. Arthur, Poulton E. Charles. 1967. Plant Communities and Environmental Interrelationships in a Portion of the Tillamook Burn, Northwestern Oregon. Ecology. 49:1.

Bormann, B.T., Cronmack,K.,Russell 1ll, W.O. 1994. "Influences of red alder in soils and long term ecosystem productivity". In The Biology and Management of Red Alder. D.E. Dibbs, D.S. DeBell, R. Tarrant (eds) Oregon State University Pres, Corvallis, Oregon

Cal Fire. 2009. Incident Information Lockheed Fire. Retrieved from http://cdfdata.fire.ca.gov/incidents/incidents details info?incident id=361

California Forest Practice Rules, 2013. California Department of Forestry and Fire Protection, Title 14, California Code of Regulations, Chapters 4, 4.5, and 10, Sacramento, CA.

Colgate, Keven Ann and others. 2001. Ecosystem's Management Report - Scotts Creek Watershed Assessment.

Compton E. Jana, Church M. Robbins, Scott T. Larned, William E. Hogsett. 2003. Nitrogen Export from Forested Watersheds in the Oregon Coast Range: The Role of $\mathrm{N}_{2}$-fixing Red Alder. Ecosystems (2003) 6:773-785.

Davis, M. B. (1973). Pollen evidence of changing land use around the shores of Lake Washington. Northwest Sci, 47(3), 133-148.

Dellamonica, Jake \#2708. 2009. Lockheed Fire INVF Report. Case \# 09CACZU007246. State of California Department of Forestry \& Fire Protection.

Dietterick, Brian. 2009. Lockheed Fire Account. Retrieved from http://www.spranch.org/files/LockheedFireAccount-BD_090909.pdf 
Dwire, Kathleen A., and J. Boone Kauffman. "Fire and riparian ecosystems in landscapes of the western USA." Forest Ecology and Management 178.1 (2003): 61-74.

Fonda, R. W. 2001. Postfire response of red alder, black cottonwood, and bigleaf maple to the whatcome creek fire, Bellingham, Washington. Northwest Science, Vol. 75, No. 1.2001.

Halofsky, E. Jessica, Hibbs E. David. 2008. Determinants of riparian fire severity in two Oregon fires, USA. Can. J. For. Res 1959-1973.

Halofsky, E. Jessica, Hibbs, E. David. 2009. Controls on early poste-fire woody plant colonization in riparian areas. Forest Ecology and Management 258 1352-1358.

Hardy, John. 2012. Post-Fire Response of Red Alder Swanton Pacific Ranch, CA. Senior Project, Cal Poly SLO.

Harrington, A. Constance. 2006. Biology and ecology of red alder. General technical report PNW-GTR-699.

Harrington, A. Constance. 1984. Factors influencing initial sprouting of red alder. Canadian Journal of Forestry Research. 14: 357-361.

Harrington, C.A.; Curtis, R.O. 1986. Height growth and site index curves for rcd alder. Res. Pap. PNW-358. Portland. OR: U.S. Department of Agriculture, Forest Service, Pacific Northwest Research Station.

Hibbs E. David, Debell S. Dean, Robert F. Tarrant. 1994. The Biology \& Management of Red Alder. Corvallis, Oregon: Oregon State University Press.

Johnson, F.D. 1968. Taxonomy and distribution of northwestern alders. Trappe, J.M.; Franklin, J.F.; Tarrant, R.F.; Hansen, G.M., eds. Biology of alder. Portland, OR: U.S . Department of Agriculture. Forest Service, Pacific Northwest Range and Experiment Station: 9-22.

Maser, C., and J.R. Sedell. 1994. From the forest to the sea: The ecology of wood in streams, rivers, estuaries, and oceans. Delray Beach, FL: St. Lucie Press.

Ministry of Forests, Lands and NRO. 2011. Smalian's Formula 4-1. Retrieved from http://www.for.gov.bc.ca/ftp/hva/external/!publish/web/manuals/scaling/chapters/ Ch4.pdf

Minore, Don, Weatherly, G. Howard. 1993. Riparian tree, shrubs, and forest regeneration in the coastal mountains of Oregon. New Forests 8: 249-263.

Naiman, J. Robert, Decamps, Michael E. McClain. 2005. Riparia. Elsevier. China. 
Naiman J. Robert, Bechtold Scott, Deanne C. Drake, Joshua J. Latterell, Thomas C. O'Keefe, and Estelle V. Balian. 2003. Origins, Patterns, and Importance of Heterogeneity in Riparian Systems. In Ecosystem Function in Heterogeneous Landscapes. Springer.

Perkins, D, White, R. 2009. Lockheed Fire Burn Severity Map. Created for and located at Cal Poly Swanton Pacific Ranch.

Perkins, D. A. 2012. Evaluating Geomorphic Change in Little Creek Using Repeated Cross-Sectional and Longitudinal Profile Surveys. Master's Thesis, Cal Poly SLO.

Pettit E. Neil, Naiman J. Robert. 2007. Fire in the Riparian Zone: Characteristics and Ecological Consequences. Ecosystems (2007) 10:673-687.

Reeves, H. Gordon, Bisson, A. Peter, Rieman, E. Bruce, Benda, E. Lee. 2006. Postfire logging in riparian areas. Conservation Biology Volume 20, No. 4, 994-1004.

Scotts Creek Watershed Council. 2003. Scotts Creek Watershed Assessment Volume 1.

Smith, G.W. Jacob. 2010. Large Woody Debris Characteristics in Little Creek at Swanton Pacific Ranch. Senior Project, Cal Poly SLO.

Sorenson, Jo Anne. 1989. Managing wildlife associations with riparian systems. USDA Forest Service Gen. Tech. Rep. PSW-110.

Strahler, A.N., 1964. Quantitative geomorphology of drainage basins and channel networks. In Chow, V., (ed) Handbook of applied hydrology, New York, McGraw-Hill:39-76.

Swanton Pacific Railroad Society. Photos.

Thomas, J. W., C. Maser, and J.E. Rodiek. 1979. Wildlife habitats in managed rangelands-- the Great Basin of southeastern Oregon. Riparian Zones. USDA Forest Service General Technical Report PNW-80.

Uchytil, Ronald J. 1989. Alnus rubra. In: Fire Effects Information System, (online). U.S. Department of Agriculture, Forest Service, Rocky Mountain Research Station, Fire Sciences Laboratory.

West, J A. (2009). Traversing Swanton Road. Unpublished data.

White, R. A (2010). Accuracy of Forest Road and Stream Channel Characteristics Derived From Lidar in Forested Mountain Conditions. Master's thesis, Cal Poly SLO. 
Worthington P. Norman, Ruth H. Robert, Elmer Matson. 1957. Red Alder - Its management and Utilization. Pacific Northwest Forest and Range Experiment Station, Forest Service.

Worthington, N.P.; Ruth, R.H.; Matson, E.E. 1962. Red alder: its management and utilization. Misc. Publ. 881. Portland, OR: 1T.S. Department of Agriculture. Forest Service, Pacific Northwest Range and Experiment Station 
APPENDIX 



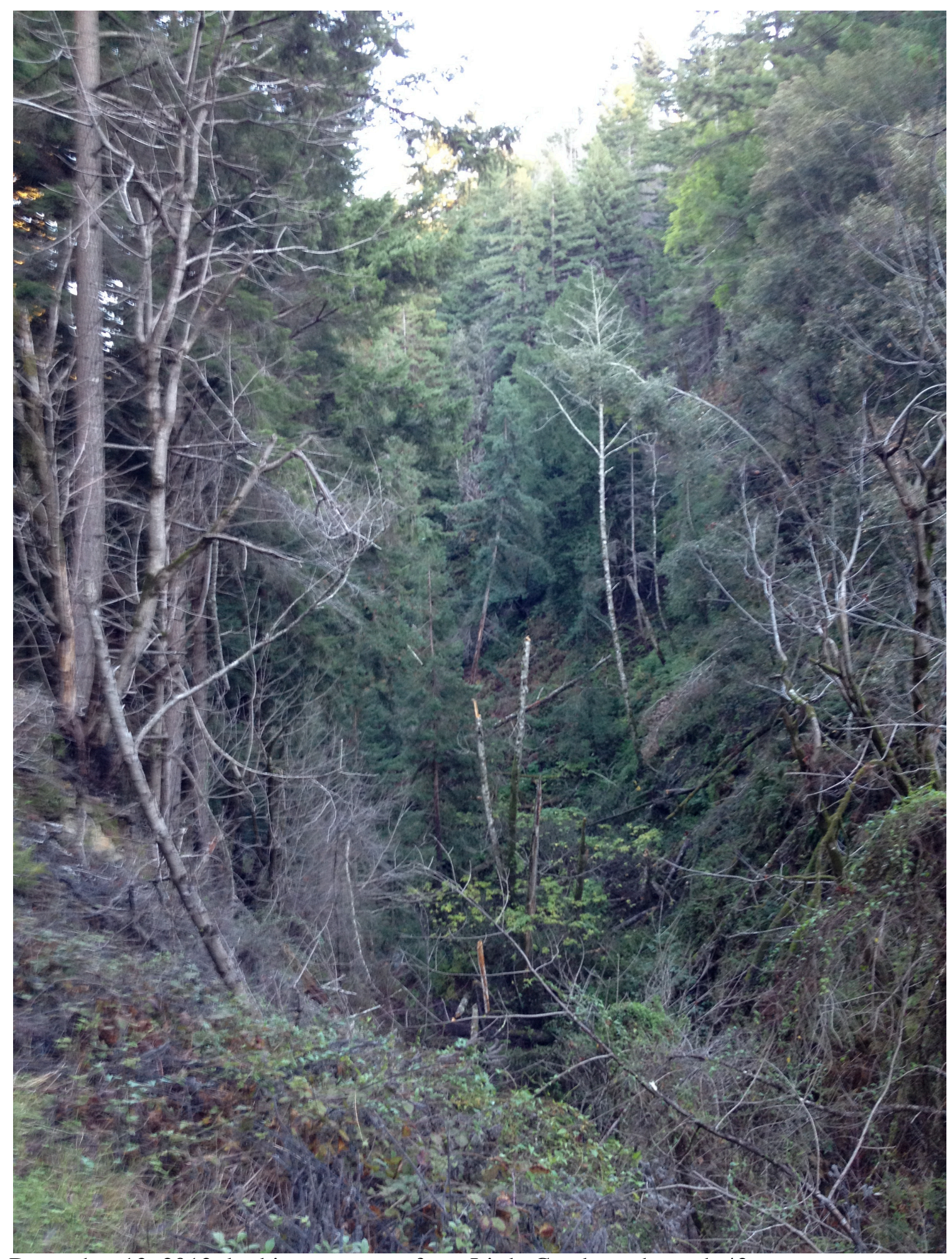

December 13, 2012, looking upstream from Little Creek road, reach 42. 


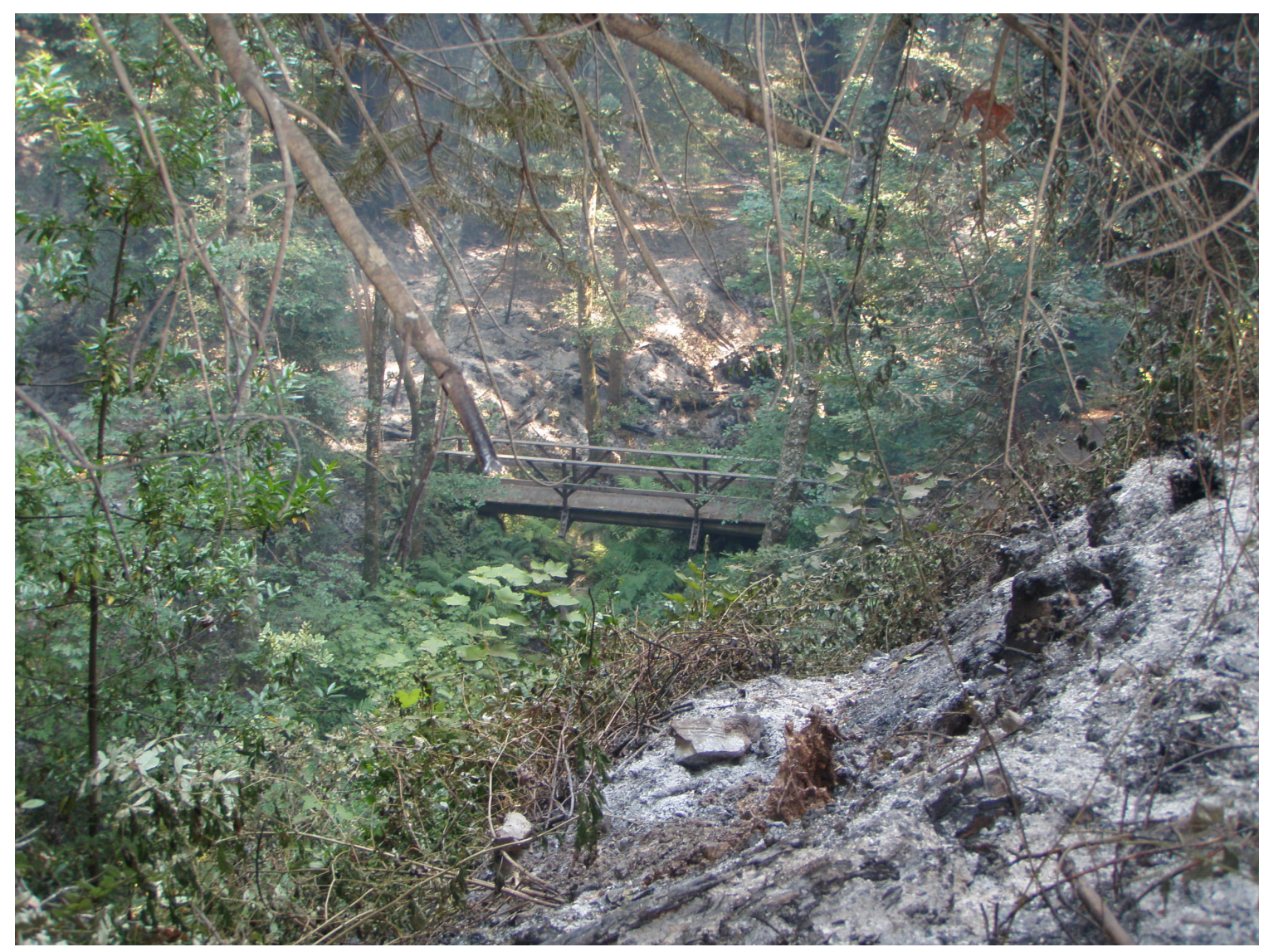

August 2009, looking down stream at RABI Bridge, North Fork Little Creek (Dietterick, 2009) 


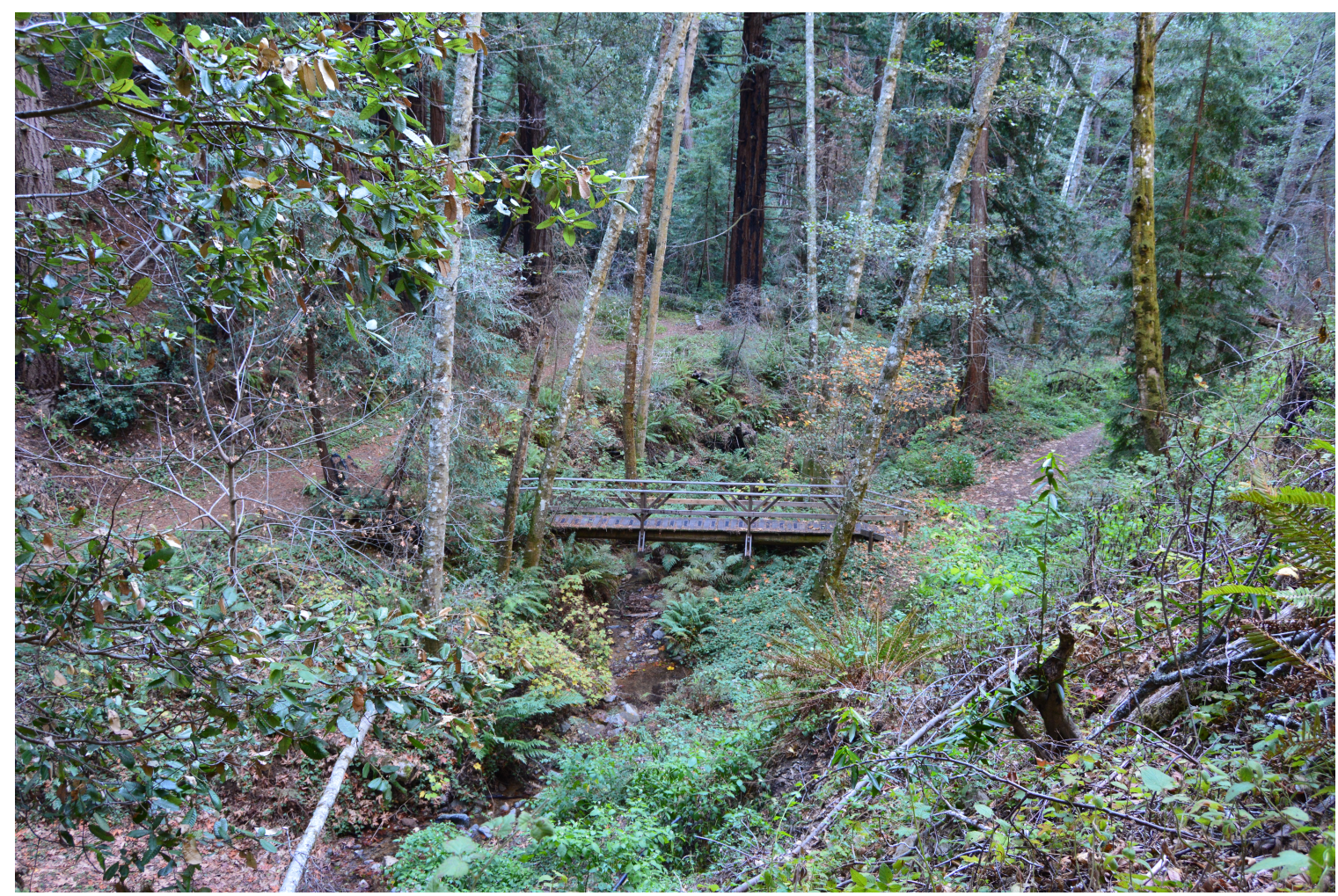

December 10, 2013, looking down stream at RABI Bridge, North Fork Little Creek 


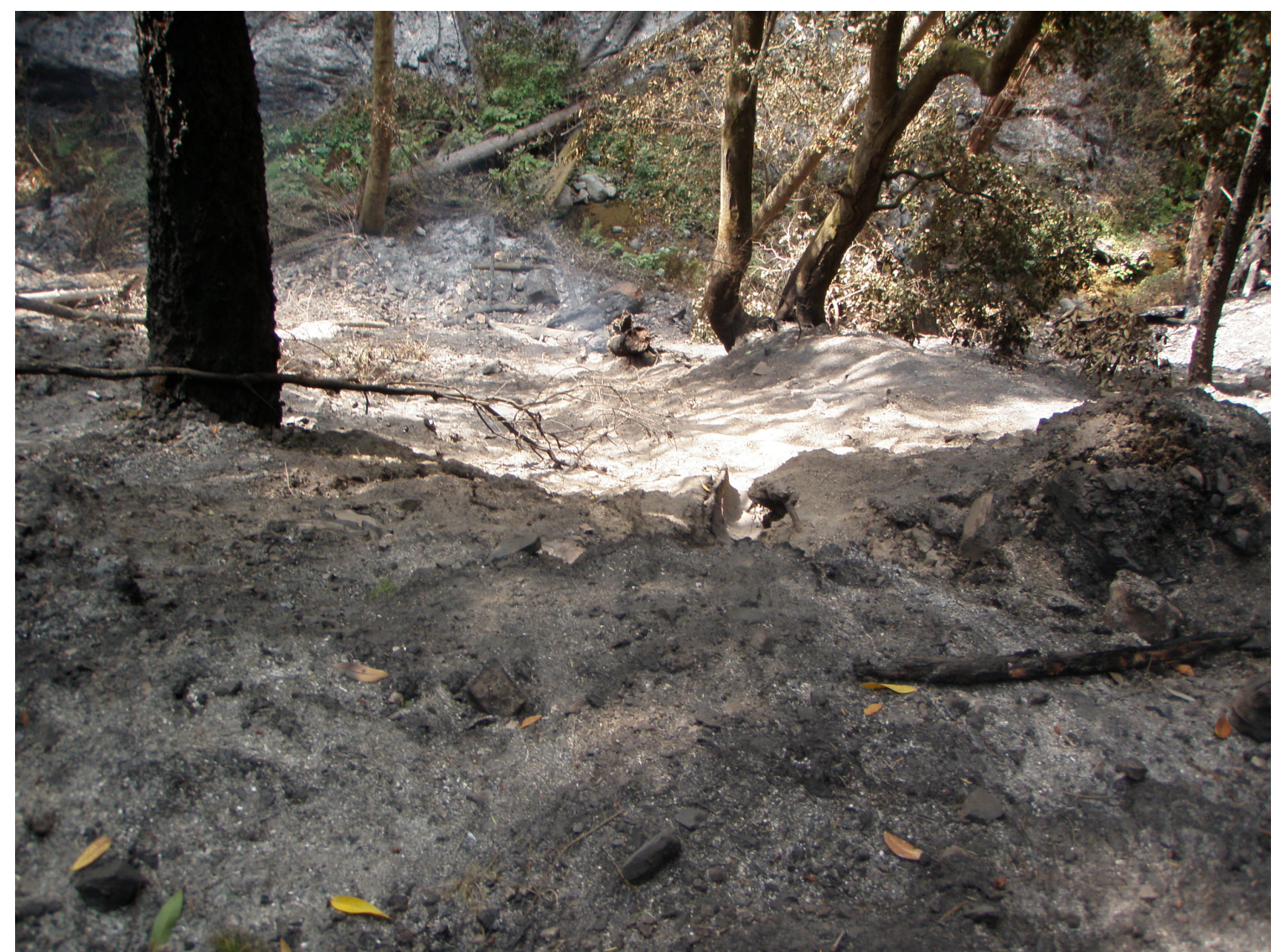

August 2009, looking down on Main Stem Little Creek from Little Creek Road near reach 38 (Dietterick, 2009) 


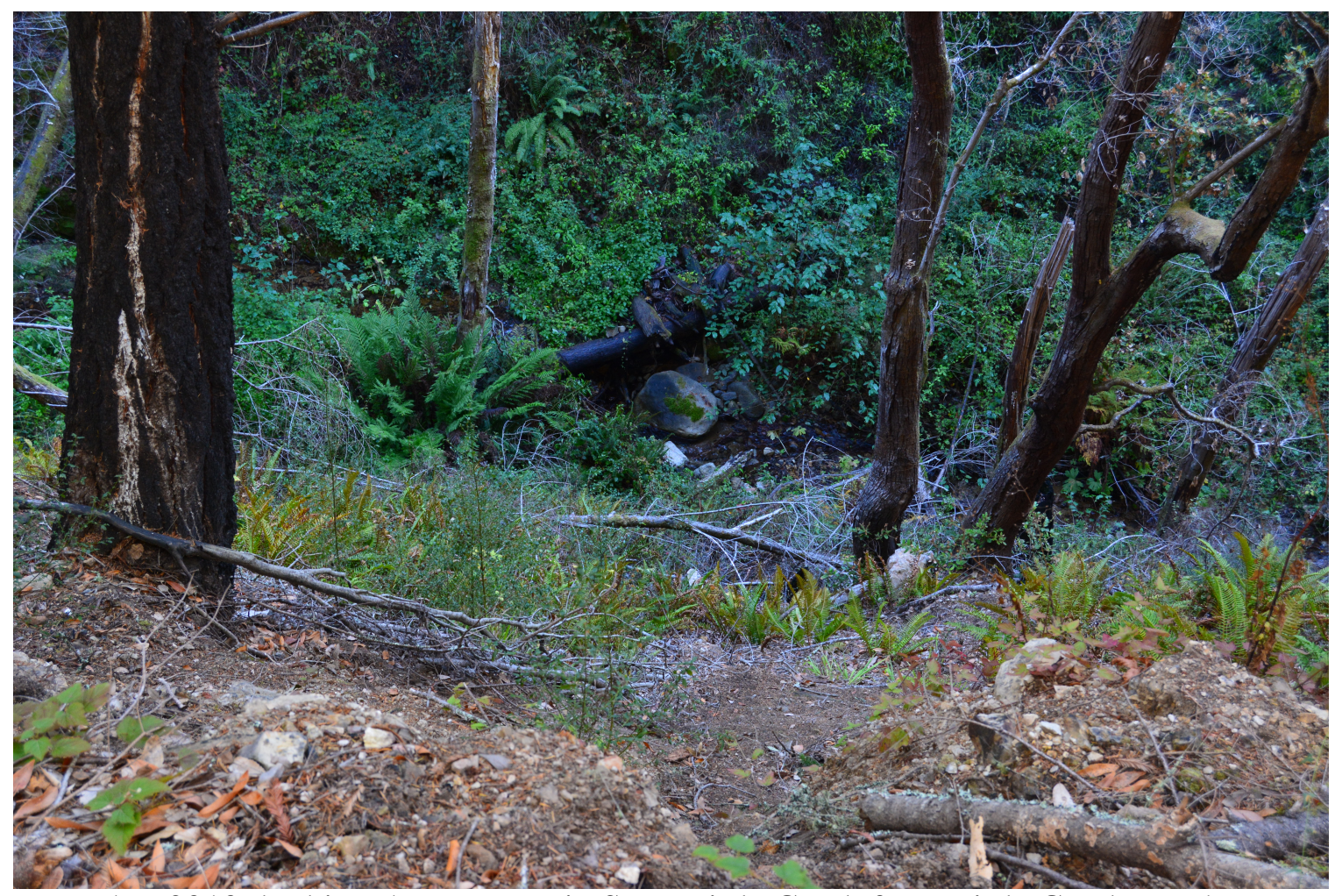

December 2013, looking down on Main Stem Little Creek from Little Creek Road near reach 38 . 


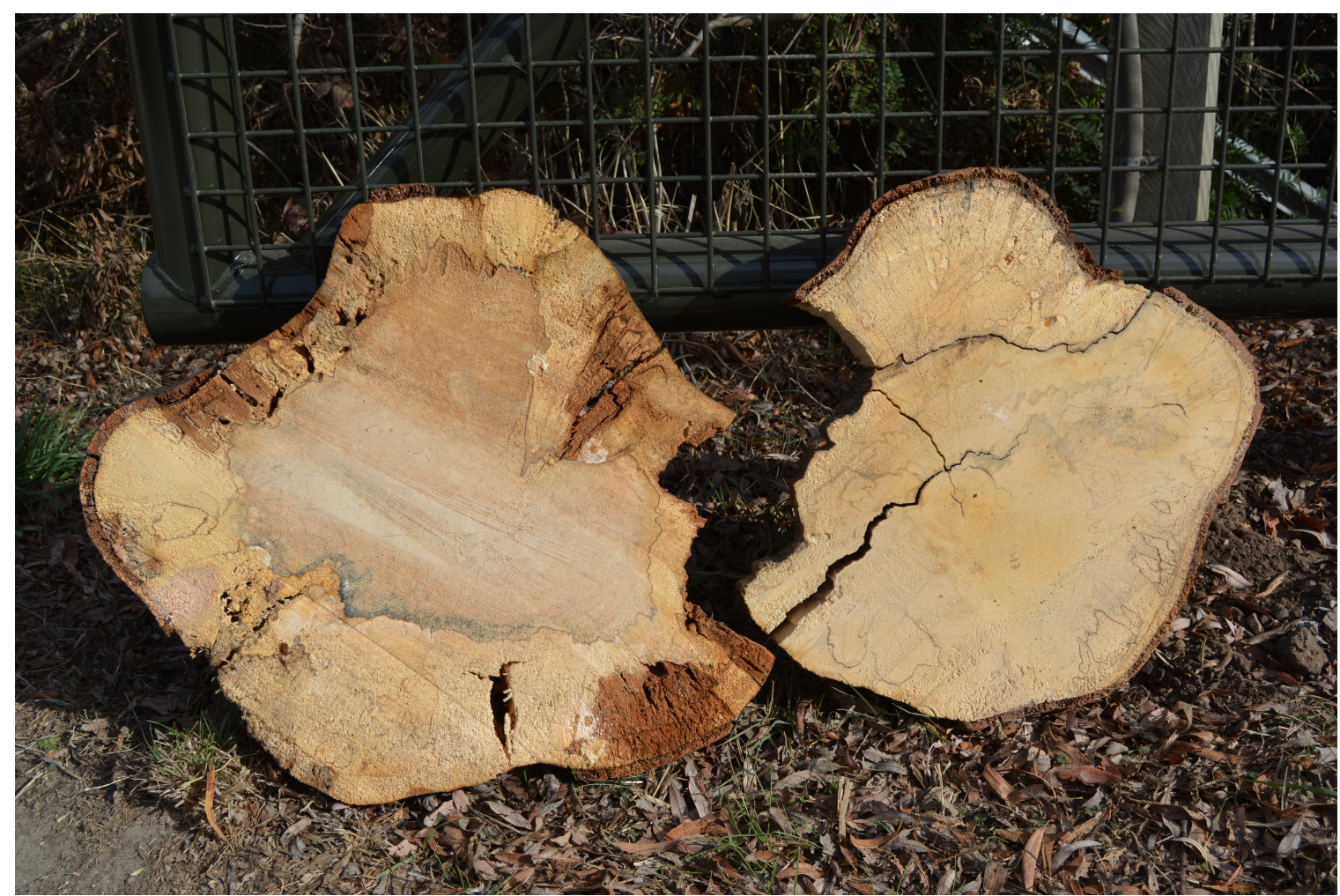

Cross-sections of red alder used for aging. Right cross-section aged at 43 years old. Unable to age left cross-section due to rot around outside. 